\title{
Güç Dengesi Teorisi Perspektifinden Birleşmiş Milletler ${ }^{1}$
}

\author{
Ege DEMIREL $L^{2}$
}

\begin{abstract}
Özet
Güç Dengesi Teorisi, birçok konu ve/veya sorun kapsamında araştırmalara ve çalışmalara teorik ve kavramsal çerçeve sunmuştur. Genel olarak literatürdeki çalışmalar dikkate alındığında bu teorinin, güç dengesini devletler ya da ittifaklar arasında sistemdeki güç dağılımını korumaya ya da değiştirmeye yönelik izlenen politikalar sonucunda ortaya çıkan güç formu olarak ele aldığ görülmektedir. Teorinin çalışma alanlarına bakıldığında ise; klasik bağlamda devletler arası ilişkiler ve özellikle XIX. yüzyıl Avrupa'sı teorinin önemli inceleme alanlarından birisi olmuştur. Öte yandan, söz konusu bakış açısı, uluslararası ilişkiler ve uluslararası politika bakımından, sadece devletler arasında değil aynı zamanda pek çok konu, alan ya da aktör düzeyinde de ele alınabilir. Bu çalışmada ise; teorinin çok fazla tercih edilmediği uluslararası örgütler düzeyi incelenecektir. Bu kapsamda Birleşmiş Milletler, Güç Dengesi Teorisi perspektifinden bakılarak ele alınacaktır. Çalışmada, BM'nin güç dengesi bakımından nasıl bir rolü ve işlevi olduğu sorgulanacaktır. Bu sorgulama yapılırken örgütün hem Soğuk Savaş dönemi hem de Soğuk Savaş sonrasındaki dönemi incelenecektir. Ayrıca çalışmada, BM'nin devletler tarafindan hangi politikalarla bir güç dengesi aracı olarak kullanıldığı irdelenecektir.
\end{abstract}

Anahtar Kelimeler: Güç, Güç Dengesi, Güç Dengesi Teorisi, Birleşmiş Milletler.

\section{From The Balance of Power Theory Perspective The United Nations}

\begin{abstract}
Balance of Power Theory provides theoretical and conceptual framework for researches and studies in many subjects and/or problems. In general, when the studies in the literature are taken into consideration, it is seen that this theory treats the balance of power, as a form of power that emerges as a result of the policies pursued in order to maintain or change the distribution of power in the system between states or alliances. When the study areas of the theory are examined; interstate relations in the classical context and especially Europe in the XIX. century have become one of the important fields of the study. On the other hand, in terms of international relations and international politics, this perspective can be addressed not only among states but also at the level of a wide range of topics, areas or actors. In this study; the level of international organizations where theory is not preferred much will be examined. In this context, the United Nations will be examined from the perspective of Balance of Power Theory. In this study, the role and function of the UN in terms of balance of power will be questioned. During this questioning, both the Cold War period of the organization and the post-Cold War period of the organization will be examined. In addition, it will examine which policies that the UN is used as a balance of power by the states.
\end{abstract}

Keywords: Power, Balance of Power, Balance of Power Theory, United Nations.

\footnotetext{
${ }^{1}$ Bu makale, yazarın "Uluslararası İlişkilerde Güç Kavramı Kapsamında BM Güvenlik Konseyi" adlı doktora tez çalışması ile ilgili olarak hazırlanmıştır.

${ }^{2}$ Doktora öğrencisi, Kırıkkale Üniversitesi Sosyal Bilimler Enstitüsü Uluslararası İlişkiler A.B.D., egedemirel5@gmail.com
} 


\section{Giriş}

Hem sosyal bilimlerin birçok alanında hem de Uluslararası İlişkiler disiplininde güç kavramı ve güç olgusu önemli bir başvuru aracı olarak işlev görmektedir. Bu bağlamda birçok konu, alan ve sorun güç kavramı ve güç olgusu çerçevesinden ele alınmaktadır. Güç Dengesi Teorisi de bu çerçevede Uluslararası İlişkiler disiplininde pek çok çalışmada kullanılan bir teori olmuştur. Güç Dengesi Teorisi, devletler arası ilişkilerde Realistlerin sıfır toplamlı oyun, göreceli kazançlar, rekabet ve çatışma gibi ilkeler etrafında ele aldıkları sorunsalları incelerken kullandıkları önemli bir teorik araç olarak nitelendirilebilir.

$\mathrm{Bu}$ teori klasik anlamda devletler arası ilişkiler analiz edilirken kullanıldığı üzere; uluslararası örgütler açısından da ele alınabilir. Örneğin; NATO-Varşova Paktı veya AB-ŞïÖ veya NATO-ŞiÖ gibi çeşitli örgütler arasında karşılaştırmalar yapılarak Güç Dengesi Teorisi perspektifinden bazı çıkarımlar elde etmek mümkündür. Çünkü bahsi geçen örgütler arasında da güç dengesini sağlamak için bazı girişimler yapılmaktadır. Bu girişimlerin çeşitli politikalar ile uygulamada somut olarak görüldüğü söylenebilir. Örneğin; NATO’nun SSCB'yi/Rusya'yı çevreleme politikası uygulayarak güç dengesini sağlamaya çalışması ya da kendi lehine güç dengesini bozmaya çalışması bu bağlamda aktarılabilir. Aynı şekilde, Birleşmiş Milletler de bu kapsamda değerlendirilebilecek örneklerden birisidir.

$\mathrm{Bu}$ nedenle, bu çalışmada güç dengesi teorisi perspektifinden BM örgütü analiz edilmeye çalışılacaktır. Teorinin BM özelinde geçerlilik taşıyıp taşımadığı irdelenerek teori BM örgütü üzerinden test edilecektir. Bu kapsamda öncelikle çalışmanın ilk bölümünde Güç Dengesi Teorisi genel hatlarıyla ve temel kaynaklar esas alınarak aktarılmaya çalışılacaktır. Bu esnada teorinin ana varsayımları ve kullandığı kavramsal araçlar ele alınacaktır. Diğer taraftan güç dengesi hakkında belirtilen görüşler ve varsayımlar arasındaki benzerlikler ve farklılıklar dikkate alınarak kavramın ve teorinin genel mantığı aktarılmaya çalışılacaktır. Dönemsel olarak ise gerek Soğuk Savaş dönemi gerekse Soğuk Savaş sonrası dönem irdelenecektir. Ardından çalışmanın ikinci bölümünde Güç Dengesi Teorisi, Birleşmiş Milletler örgütü analiz edilirken teorik bağlamda sorgulanacaktır. Ayrıca belirtmek gerekir ki; gerekli yerlerde Birleşmiş Milletler'in Milletler Cemiyeti'nin bir anlamda devamı olarak değerlendirildiği için MC'ye yönelik bazı önemli noktaların üzerinde durulacaktır. Bu kapsamda, BM'ye dair bazı çıkarımlar elde edilecektir. Bu kısımda, örgütün güç dengesi ile ilişkisi değerlendirilecektir. Bu nedenle BM'nin hangi politikalar ya da araçlar açısından güç dengesi ile ilişkilendirilebileceğine dair açıklamalar yapılacaktır. Bunun dışında somut olarak örnek olaylar üzerinden açıklamaların daha anlaşılır olması sağlanmaya çalışılacaktır.

Çalışmanın amacı ise; Güç Dengesi Teorisi'nin BM’nin analizinde kullanılabilecek bir teorik çerçeve imkânı sunduğunu ortaya koymaktır. Yani BM örgütünün güç dengesi bakımından ele alınabilecek bir aktör olduğu iddiası çalışma içerisinde sunulmaya çalışılacaktır. Öte yandan, bu 
çalışmada; analiz yöntemi olarak nitel yöntem kullanılmıştır. Bunun dışında örnek olay incelemeleri tekniği de kullanılarak teorinin varsayımları test edilmeye çalışılmıştır.

\section{Güç Dengesi Teorisi}

Güç dengesi, incelenen zaman, mekân, aktör unsurları ve uluslararası sistemin yapısı temelinde farklı şekillerde değerlendirilebilmektedir. Bu nedenle güç dengesi bazen eşit bir güç dağılımına işaret ederken, bazen de bir devlet açısından güç dengesi kendi lehine olan güç konsolidasyonu olarak nitelendirilebilmektedir. Bazı durumlarda güç dengesi dört-beş devlet arasında sınırlı bir coğrafyada tezahür ederken bazı durumlarda ise; iki devlet ya da iki ittifak grubu arasında bütün uluslararası sistemi kapsayacak şekilde etki doğurabilir. Bu açıdan güç dengesi hakkında birtakım açıklamalar yapmadan önce bu terimin üzerinde uzlaşılan ve kesin olarak belirli sınırlar dâhilinde ele alınan bir duruma karşılık gelmediği uyarısını öncelikle akılda tutmak gerekmektedir. Bu noktada bahsedilen hususları da dikkate alarak artık, güç dengesi üzerine literatürdeki açıklamalara ve değerlendirmelere geçilebilir.

Morgenthau, güç dengesi kavramını dört farklı anlam çerçevesinde ele almaktadır. Buna göre, birincisi; güç dengesi, belirli bir duruma yönelik bir politika şeklinde değerlendirilebilir. İkincisi, güç dengesinin fiili bir duruma karşı yapıldığı iddia edilebilir. Üçüncüsü, güç dengesi ile yaklaşık olarak gücün sistemde eşit bir şekilde dağılımı kastedilebilir. Son olarak dördüncüsü, akla gelebilecek herhangi bir güç dağılımına karşılık olarak bu kavram öne sürülebilir (Morgenthau, 1948: 125).

Güç dengesinin pek çok farklı anlamı olduğunu belirten Scweller de 7 farklı şekilde bu terimi ifade etmektedir: Birincisi, güç dengesi eşit ölçüde bir güç dağılımı şeklinde anlaşılabilir. İkincisi gücün eşit olarak dağıtılması gerektiği ilkesi olarak belirtilebilir. Üçüncüsü, belirli bir zamanda var olan güç dağılımı olarak nitelendirilebilir. Dördüncüsü, zayıf aktörlerin zararına olacak bir şekilde büyük güçler arasında kurulan denge biçiminde düşünülebilir. Beşincisi, gücün eşit bir şekilde dağılmasını engellemek amacıyla güç bakımından baskın olmanın gerekli olduğu ilkesi olarak belirtilmektedir. Altıncısı, bir devletin dengeleyici rolünü üstlendiği ve sistemde taraflar arasında dengenin korunmasını sağlayan bir işlevi yerine getirdiği bir yapı için de bu terim tercih edilebilir. Son olarak yedincisi, güç dengesi uluslararası politikanın doğasında var olduğu iddia edilen gücün eşit bir şekilde dağılımını üreten bir eğilim anlamında kullanabilmektedir (Schweller, 2016: 3).

Burada belirtilen güç dengesi sistemindeki dengeleyici aktörün rolü bütünleştirici bir rol olarak nitelendirilebilir. Çünkü bu aktör sistemde hiçbir ittifakın baskın bir konuma gelmesine müsaade etmemekte böylece sistemin bütünsel olarak varlığını sürdürmesine katkı vermektedir. Buna karşın gevşek iki kutuplu sistemde ise; bu aktörün rolü, bir aracı rol şeklinde değerlendirilebilir. Çünkü bu sistemde dengeleyici aktör taraflardan birisine katılma davranışı yerine aracı rolü üstlenmeyi tercih edecektir. Bu sistemde bütünleştirici rolü ise; evrensel aktör veya bloklara dâhil olmayan bir aktör üstlenebilir (Kaplan, 1957: 691). 
Haas ise; güç dengesinin anlamına ilişkin değerlendirmeleri sekiz farklı başlık altında toplamıştır. Buna göre, güç dengesi; ilk olarak, eşit bir güç dağılımı şeklinde incelenebilir. İkincisi tam bir dengeye karşılık olarak kullanılabilir. Üçüncüsü, bazen hegemonya kavramı dahi güç dengesi anlamında ele alınabilir. Dördüncüsü, istikrar ve barış anlamına gelebilir. Beşincisi, istikrarsızlık ve savaş kelimeleri de güç dengesini ifade ederken kullanılabilir. Altıncı olarak, güç dengesi genel olarak güç politikaları biçiminde anlaşılabilir. Yedincisi, güç dengesi evrensel hukuk tarihine karşılık olarak da söylenebilir. Son olarak sekizinci anlamda, güç dengesi sistem ve bir tür politika gösterici olarak algilanabilir (Haas, 1953: 447-458).

Güç dengesinin farklı anlamları konusunda yapılan bir diğer çalışma Wight'a aittir. Wight, sınıflandırmasını dokuz başlık altında ortaya koymuştur. Buna göre: 1- Güç dengesi, eşit bir güç dağılımı biçiminde değerlendirilebilir. (Burada eşit güç dağılımının var olduğu kabul edilmektedir.) 2Güç dengesi, gücün eşit olarak dağıtılması gerektiği ilkesine atfen ele alınabilir. (Burada ise; eşit güç dağılımının var olması ideal bir durum olarak ele alınmaktadır.) 3-Güç dengesi sistemde mevcut olan güç dağılımı olarak anlaşılabilir. 4- Zayıf güçlerin zararına olacak bir şekilde büyük güçlerin aralarındaki güç bakımından eşitliği şeklinde nitelendirilebilir. 5- Güç bakımından zayıf olan tarafa yapılacak bir güç transferi ile yani güçlü bir devletin zayıf tarafa eklemlenmesiyle ortaya çıkacak güç durumundaki dengesizlik riskinin önüne geçilerek güç dengesinin kurulması olarak da ifade edilebilir. 6- Gücün dengelenmesi için bir aktörün özel bir rol üstlendiği zaman da güç dengesinden bahsedilebilir. Yani burada bir dengeleyici aktör mevcuttur. 7- Ya da mevcut güç dağılımında bir aktörün daha fazla güce sahip olduğu durum da bir çeşit güç dengesi olarak değerlendirilebilir. 8Sistemde bir gücün baskın olarak bulunduğu bir yapı dahi güç dengesi şeklinde incelenebilir. 9Ayrıca güç dengesi, uluslararası politikanın doğasından kaynaklanan eşit bir güç dağılımın üretilmesi eğilimi şeklinde de okunabilir (Wight, 1966: 151).

Somut olarak güç dengesi sistemi XX. yüzyıldaki uluslararası sistem temelinde incelendiğinde dört farklı sistemik dağılım olduğu söylenebilir: İlk dönem; I. Dünya Savaşı öncesi dönemi betimlemektedir. Bu dönem; XIX. yüzyıldan 1914'e kadar olan zaman zarfını kapsamaktadır ve sistemde büyük Avrupa imparatorluklarının hâkim olduğu bir durumdan bahsedilebilir. Söz konusu dönem güç dengesi olarak nitelendirilmektedir. Ancak 1910'da güç dengesi sisteminin bozulduğu görülmektedir. İkinci dönem; I. Dünya Savaşından II. Dünya Savaşı sonuna kadar olan gelişmeleri ele almaktadır. Bu dönemde imparatorluklar arasında yaşanan mücadeleler olmuştur. Fakat belirtmek gerekir ki; iki savaş arası dönem bir tür güç dengesizliği olarak değerlendirilebilir. Sistem bu dönemde istikrarsız bir yapıdadır. Üçüncü dönem; Soğuk Savaş olarak belirtilebilir. Klasik Avrupa güçlerinin ortadan kalktığı ve ABD ile SSCB gibi iki süper gücün başat konumda olduğu iki kutuplu bir sistem söz konusu olmuştur. Dördüncü dönem ise; Soğuk Savaş sonrası gelişmeleri kapsamaktadır. SSCB’nin dağılmasıyla birlikte iki kutuplu sistem ortadan kalkmıştır. Bu dönem için farklı değerlendirmeler 
mevcuttur. Çok kutupluluk, medeniyetler arası çatışma ve küreselleşme olgusu bu dönem hakkında yapılan tartışmalarda öne çıkan konu başl1klarıdır (Roskin ve Berry, 2014: 27-28).

Soğuk Savaş sonrasında yapılan tartışmalar ve analizlerden genel olarak bir çıkarsama yapılacak olursa; XX. Yüzyılın son on yılının bir anlamda tek kutuplu bir sistem olarak değerlendirilmesi mümkün olabilir. Çünkü süper güçlerden birisi olan SSCB dağılma süreci yaşamıştır. SSCB'nin en önemli bileşeni olan Rusya doğal olarak hem ekonomik hem de siyasal açıdan yeniden bir kuruluş aşaması geçirmek durumunda kalmıştır. Rusya siyasal, sosyal ve ekonomik açıdan bu dönemi sorunlarla boğuşarak ve yeniden yapılanma süreci ile geçirmiştir. Diğer taraftan $\mathrm{ABD}$ ise; tek süper güç konumunun avantajlarından yararlanarak hem NATO'nun üye sayısı hem de faaliyet alanı bağlamında genişlemesiyle hem de genel ekonomik tablosundaki verilerle sistemi domine etmeye başlamıştır. $\mathrm{Bu}$ anlamda bu dönem için tek kutuplu sistem değerlendirmelerinin temelsiz olmadığı iddia edilebilir.

Ancak XXI. yüzyıla girildikten sonra, hem Rusya'nın sisteme adapte olması, siyasal, ekonomik ve sosyal açıdan yaşadığı pek çok sorunu çözüme kavuşturması ve bunun sonucunda güçlenmesi hem de Çin gibi bir aktörün ABD'nin küresel liderliğini tehdit eder bir konuma erişmesi söz konusu tek kutupluluğu sorgulamaya açmıştır. Ayrıca 11 Eylül saldırıları ile birlikte asimetrik tehditlerle süper gücün dahi savunma zafiyeti göstermesi bu analizin yeninden değerlendirilmesine yol açmaktadır. Bunun dışında, Almanya'nın son dönemde ekonomi alanında rekabet gücünü artırması önemli bir gelişmedir. Ayrıca Almanya, AB-Eurozone aracılığıyla ekonomik-siyasal bağlamda daha etkili bir güç olmaya başlamıştır. Son olarak Çin ve Rusya'nın da içinde yer aldığı BRIC/S grubunun sisteme yönelik artan revizyonist talepleri dikkate alınmalıdır. Bu açıdan bu dönem için çok kutuplu bir dünya nitelendirmesi yapılabilir. Bu yüzden tekrar sistemdeki güç dağılımının dengeye oturtulması için veya dengenin kendi lehlerine bozulması için aktörler tarafindan çaba gösterildiği ve güç dengesinin halen devletler nezdinde karşılık bulduğu söylenebilir.

Burada, kısaca güç dengesinin genel mantığı şu şekilde aktarılabilir: Bir devlet veya bir devletler gurubu aşırı bir şekilde güçlendiği zaman, bu durum diğer devletler tarafından bir güvenlik tehditi şeklinde algılanacaktır. $\mathrm{Bu}$ ise; devletlerin bireysel ya da grup halinde askeri güçlerini artırmalarına yol açabilecektir. İşte bu şekilde sağlanmaya çalışılan dengeleme süreci sistemin ana operasyonel kuralı olarak değerlendirilmektedir. Fakat bu dengeleme sürecinin uygulamada nasıl gerçekleşeceği konusunda farklı düşünceler mevcuttur. Örneğin; Claude ((Claude, 1962); (Claude, 1989)), güç dengesi için üç farklı senaryodan bahsetmektedir. Birincisi, sistemin otomatik olarak kendi kendini düzenleyen ve dengeyi sağlayan bir formda olduğu düşünülebilir. İkincisi; sistemde, bir dengeleyici sayesinde söz konusu sürecin yarı otomatik bir şekilde işlemesi mümkündür. Üçüncüsü, manuel olarak devletlerin sistemin dengeye oturması için reaksiyon göstermesidir. Yani burada devlet adamlarının ya da diplomatların inisiyatif almalarından söz edilebilir (Schweller, 2016: 5). 
$\mathrm{Bu}$ açıdan güç dengesi sistemi, birkaç ana aktörün birbirine yakın güçlere sahip olduğu ve birbirlerini ittifaklarla dengeleyebilecekleri bir yapı olarak analiz edilebilir. Örneğin bu sistemde; A devleti $\mathrm{B}$ devleti tarafından tehdit edildiğini düşünürse; onu caydırmak amacıyla $\mathrm{C}$ devletiyle ittifak kurma stratejisini benimseme yoluna gidebilir. Başka bir dönemde bu üç devlet gittikçe güçlenen bir D devletine karşı bir araya gelerek yeni bir ittifak formu ortaya çıkarabilirler. Bazı durumlarda bu yöntemle sonuç alınamasa dahi; yine de böylece savaşların şiddetini ve sayısını azaltmanın mümkün olduğu görülmüsşür. Literatürde, güç dengesi sisteminin işlemesine yönelik, bir ortak kültürün ve sistemin devamına yönelik bir iradenin olması gerektiğinden söz edilmektedir. Ayrıca sistemde en az beş aktörün varlığı gerekli görülmektedir. Aktarılan hususları dikkate alarak güç dengesi bir analojiyle ifade edilerek şu şekilde özetlenebilir: Aslında güç dengesi, tıpkı bir poker oyununu andırmaktadır. Çünkü pokerde de oyuncuların bütün parayı kazanma stratejisini benimsemeyerek, oyunun devam etmesini tercih ettikleri bilinmektedir. Bu nedenle oyuncuların iflas etmesi arzulanan bir sonuç değildir ve oyuncular buna göre hareket eder (Roskin ve Berry, 2014: 29-30). Aynı şekilde güç dengesi sistemi de bu şekilde işlemektedir.

$\mathrm{Bu}$ noktada, iki devlet arasında güç dengesinin kurulması için iki ana yöntemden bahsedilebilir. Birinci yöntemde, zayıf olan taraf, kendi ulusal gücünü artırarak karşı tarafı dengelemeye çalışabilir. Tabi eğer bir koalisyon söz konusu ise kendi koalisyonunda yer alan devletlerin kapasitesinin artması da aynı işlevi sağlayacaktır. Elbette bahsi geçen kapasitenin artırılması durumunun güç unsurlarından birisi ya da tamamı ile ilgili olabileceğini belirtmek gerekir. Genel olarak bu konuda askeri kapasite ve silahlanmaya yönelik girişimler öne çıkmaktadır. Fakat burada bu davranışın karşı tarafı da harekete geçirerek bir silahlanma yarışına yol açabileceği hatırlatmasını yapmak gerekir. İkinci yöntemdeyse; zayıf taraf başka bir devlet ya da devletler grubu ile bir araya gelerek güç dengesini sağlamaya çalışmaktadır (Chatterjee, 1972: 53).

Zinnes ise; güç dengesinin farklı şekillerde gerçekleştiğini göstermek için; 6 farklı formül ile güç dengesini ifade etmeye çalışmıştır: 1- Sistemde hiçbir ittifakın olmadığı ve bütün devletlerin eşit güce sahip olduğu bir güç dağılımından bahsedilebilir. Yani; $A=B=C=D=E$ formülü bu ifadeyi karşılamaktadır. 2- Başka bir durumda bütün devletlerin bir ittifaka ait oldukları ve bu ittifakların güçlerinin eşit olduğu görülebilir. $\mathrm{O}$ zaman yeni formül, $\mathrm{A}+\mathrm{B}=\mathrm{C}+\mathrm{D}+\mathrm{E}$ şeklinde belirtilebilir. 3- İki eşit güçte ittifakın olduğu ancak buna karşın sistemde bir tane de tarafsız devletin olduğu bir formülasyon da olabilir. Bu durumda, $\mathrm{A}+\mathrm{B}=\mathrm{C}+\mathrm{D}$; E şeklindeki formül geçerlidir. 4- Benzer şekilde iki ittifak ve bir tarafsız devletin olduğu yapıda eğer tarafsız devlet ittifaklardan birine dâhil edilerek durum analiz edilirse; denge farklı şekilde işleyecektir. Tarafsız devletin hesaba katıldığı ittifak daha güçlü olacaktır. Böylece $\mathrm{A}+\mathrm{B} \neq \mathrm{C}+\mathrm{D}, \mathrm{E} ; \mathrm{A}+\mathrm{B}+\mathrm{E}>\mathrm{C}+\mathrm{D}$ ve $\mathrm{A}+\mathrm{B}<\mathrm{C}+\mathrm{D}+\mathrm{E}$ formülü ortaya çıkacaktır. 5- Ancak hiçbir ittifakın olmadığı ve sistemdeki her bir devletin diğerlerinin toplam gücünden daha az bir gücünün olduğu bir sistem de söz konusu olabilir. Bu kez formül şu şekilde olacaktır:

$\sum X \mathrm{X}>\mathrm{Xj}$ için; $\mathrm{j}=1, \ldots, \mathrm{N},(\mathrm{N}=$ ulus devletlerin toplam sayısını ifade etmektedir.) 
$\mathrm{i} \neq \mathrm{j}$ 6- Son olarak bir devletin ya da bir ittifakın sistemdeki diğer devletlerden güçlü olmasından söz edilebilir; ancak toplam güç durumları dikkate alındığında 5. maddedeki duruma benzer şekilde bu ittifak ya da devlet kendisi dışındakilerin toplam güçlerinden daha az bir güç formuna sahiptir. Bu yapı ise;

$\sum X i>X j$ için; $j=1, \ldots, N(N=$ ulus devletlerin toplam sayısını ifade etmektedir ve $A>B>C$ $>$ D $>$ E olmaktadır.)

$\mathrm{i} \neq \mathrm{j}$ şeklinde formülleştirilebilir (Zinnes, 1967: 272-273).

Birinci ve ikinci tanım için daha önce dile getirilen görüşlerle benzer bir tabloyu çizdiği söylenebilir. Üçüncü ve dördüncü tanımlar ise; XVIII. ve XIX. yüzyıllarda Britanya'nın sistemin dengeleyicisi olduğu güç dengesi forumuna işaret etmektedir. Beşinci madde; Avrupa Uyumu, MC ve BM gibi kolektif güvenlik sistemine benzer bir oluşumu göstermektedir. Altıncı madde de; bir çeşit denge kontrol mekanizması ya da belirli bir devlet lehine oluşan güç dengesi formu olarak nitelendirilebilir (Zinnes, 1967: 273).

Morton Kaplan ise, bu tip bir sistemde Fransa, Almanya İtalya gibi temel ulusal aktörler bulunduğunu söylemiş ve sistemin işlemesi için en az beş ulusal aktörün olması gerekli olduğunu iddia etmektedir. Kaplan güç dengesinin karakteristik özellikleri olarak nitelendirdiği ana kuralları şu şekilde belirtmiştir: 1- Devletlerin kapasitelerini artırmaya çalışmaları gerektiğini ancak savaşmak yerine pazarlığı/müzakereyi tercih etmeleri gerektiğini ileri sürmektedir. 2- Ancak kapasitenin artırılması konusunda bir başarısızlığın ortaya çıkmasına müsaade edilmemesi o zaman savaşmanın tercih edilmesini savunmaktadır. 3- Diğer taraftan sistemdeki temel aktörlerden birisinin ortadan kalkma ihtimali olursa bu durumda savaşın durdurulması üzerinde durmaktadır. 4- Sistemde baskın bir konum elde etme olasılığı olan bir koalisyon ya da devlet ortaya çıkarsa devletlerin buna karşı mücadele etmesi. 5- Ayrıca ulus üstü organizasyonel ilkeleri benimseyen aktörlerin sınırlanması gerektiğinden bahsetmektedir. 6- Sistemin işleyişi konusunda vurgulanan bir diğer unsur ise; ana aktörlerden zayıflamış olan ya da sistem dışına itilmiş aktörün sisteme tekrar dâhil edilmesi veya önemli görülmeyen aktörlerden birisini sistemin ana aktörü durumuna getirmektir (Kaplan, 1957: 686).

Yapılan açıklamalar ve incelenen örnekler 1şığında, güç dengesi teorisinin uluslararası toplumu güçlüler ve zayıflar temelinde eşitsiz bir yapıda ele aldığı iddia edilebilir. Ancak sistemde dengenin sağlanması ve devletlerin hegemonyayı ve saldırganlığı engelleyerek varlıklarını sürdürebilmeleri mümkündür. $\mathrm{Bu}$ nedenle güç dengesi teorisi geleneksel olarak Realist teori ile yakından ilişkilidir. Devlet adamları da bu çerçevede ulusal çıkarlar temelinde hareket etmektedirler. Çünkü anarşik bir düzende uzun vadeli güvenlik ve istikrar yerine devletler güç dengesini sağlama temelinde hareket edeceklerdir (Sheehan, 1996: 8). 
Güç dengesinin hâkim olduğu bir ortamda iki ana noktanın ön plana çıktığı görülmektedir. Bazı yazarlara göre; güç dengesi uluslararası alanda barışın sağlanmasına katkı sunacak bir rol oynamaktadır. Buna karşın pek çok yazar güç dengesinin barışın korunmasında etken bir faktör olarak değil de bir çeşit bu sistemin ortaya çıkardığı bir yan ürün olarak değerlendirmektedir. Bu yazarların görüşleri şu şekilde açıklanabilir. Güç dengesi sistemi, bütün devletleri denetim altında tutarak hiçbir devletin çok fazla güçlenmesine imkân vermemekte ve bu yüzden diğer devletlerin topraklarının işgal edilmesi de engellenmektedir. Kısaca ifade edilecek olursa; güç dengesi sistemi statükocu bir karaktere sahiptir. Bu nedenle bütün devletlerin bağımsızlığını garanti eder. Ancak çatışmaların olup olmayacağı konusunda kesin bir yargıya varmak mümkün değildir (Zinnes, 1967: 271).

Öte yandan Schweller ise; güç dengesi teorisinin iddia edildiği üzere asıl amacının uluslararası alanda barış ve düzenin sağlanması olmadığını ifade etmektedir. Aslında teorinin bir devletin komşularını bünyesine katarak hâkim güç olmasını engelleyerek çok devletli sistemin devam etmesini sağlamayı amaçladığını belirtmektedir. Yani burada bütün uluslararası sistemi tehdit eden bir dengesiz güce sahip olan devletlere güvenilmemesi gerektiği vurgulanmaktadır. Bu çerçevede saldırgan bir büyük gücün sistemdeki toplam kaynakların yarısından fazlasına sahip olduğunda ve diğer devletleri kendisine boyun eğdirecek bir pozisyona eriştiğinde tehlikeli bir durumun ortaya çıktığı üzerinde durulmaktadır (Schweller, 2016: 4). Güç dengesinin uluslararası alanda barış ve düzen olguları ile aralarındaki bağlantıya değinmişken, kolektif güvenlik sistemine de bir parantez açmak gerekir. Zira bu sistem; güç dengesi ve BM arasındaki ilişkiye dair yapılacak açıklamalara da 1şık tutacaktır. Zaten kolektif güvenlik sistemi oluşturulurken sistemik açıdan güç dengesi dikkate alınmıştır.

$\mathrm{Bu}$ bağlamda, sosyal sistemlerde öngörülebilirliği ele alırken birkaç unsuru özellikle vurgulamak gerekmektedir. Örneğin; karmaşıklık derecesi, temel mekanizmaların otomatik olarak mı işlediği yoksa isteğe bağlı olarak mı işlediği ve sistemin bir şekilde çalışmasını sağlamak için ana aktörlerin kısa vadeli çıkarlarına yönelik olarak hareket etmelerinin gerekli olup olmadığı gibi durumlar öngörülebilirliği etkilemektedir. Bu çerçevede anlaşma düzenlerinden bahsedilebilir. Kolektif güvenlik sistemi bu açıdan üzerinde durulabilecek somut bir örnektir. Bu tip düzenlerde geçici tercihler yerine gönüllü olarak ortak çıkarların merkeze alındığı ve ona tabi olarak hareket edildiği görülmektedir. Ancak uygulamada nasıl bir performans gösterileceğine ilişkin tahmin yürütmek oldukça zordur (Schweller, 2016: 11).

Fakat güç dengesi sistemine bakıldığında oldukça otomatik bir işleyişi olduğu ve yüksek bir oranda öngörülebilirlik derecesine sahip olduğu söylenebilir. Çünkü bu tip bir sistemde, devletlerin kısa vadeli çıkarlar gözettiği, güvenlik ve güç peşinde olduğu ve varlıklarını sürdürmek için rekabet halinde oldukları görülmektedir. Ayrıca bu sistemde kendi-kendine yardım prensibi ve anarşik düzen ilkesi geçerlidir. Ama yine de her ne kadar öngörülebilirlik seviyesi yüksek olsa da güç dengesi sisteminin çok düzgün işlediği ve daima öngörülebilir olduğunu iddia etmek yanlış olacaktır. Dengelemenin gecikebileceği, belirsiz bir dengelemenin olabileceği ya da dengelemenin hiç 
sağlanamayacağı durumlardan da söz etmek mümkündür. Fakat bahsedilen durumların devletlerin güç dengesi sisteminden bilinçli bir şekilde çıkmaya çalıştıklarında ve ancak başka bir güvenlik sistemine geçemediklerinde ortaya çıktığını hatırlatmak gerekir (Schweller, 2016: 11).

$\mathrm{Bu}$ nedenle, güç dengesi sisteminde devletlerin üç güvenlik sorunu ile ilgilenmesi gerekmektedir. Birincisi; büyük bir güç tarafından kendisine yöneltilecek doğrudan saldırı tehdidi bu kapsamdadır. İkincisi; bilinçli olarak yapılmasa bile bir büyük gücün askeri eylemlerinin diğer devletlerin güvenliğine zarar vermesi dolaylı zarar başlığı altında ilgilenilmesi gereken bir sorundur. Üçüncüsü; bir büyük gücün küresel düzlemde hegemonya kurması olasılığı ile ilgilidir. Çünkü eğer bir büyük güç küresel bir hegemon güç pozisyonunu elde ederse, kendi çıarları ekseninde hareket edecek; göreceli çıkarları temelinde dünyanın ekonomik kaynaklarını sömürecek ve ikincil düzeydeki güçlere karşı emperyal kurallar uygulama şansı elde edecek ve hatta herhangi bir devleti işgal etme imkânına da kavuşacaktır (Pape, 2005: 13).

Diğer taraftan, güç dengesinin sadece hegemonya karşıtı ittifaklar temelinde açıklanamayacağını ifade etmek gerekir. Çünkü bu çerçevede devletlerin doğal olarak kendi güvenliklerini sağlamak ve çıkarlarını artırmak açısından ittifak kurma eğiliminde oldukları unutulmamalıdır. Ayrıca güç dengesi perspektifinden bakıldığında; bazı devletlerin ortak çıkarlar temelinde kuracakları ittifak bir başka devletler grubu tarafından bu ittifaktan endişe edilerek karşıittifakın kurulmasına yol açabileceğinden de söz etmek mümkündür (Little, 2007: 4).

Ayrıca belirtmek gerekir ki; güç dengesi bakımından dengelemeden söz edildiğinde; zayıf ve güçlü arasında eşit bir durumun sağlanması kastedilmektedir. Bu dengelemenin sağlanması için güçlü devletlerin askeri bakımdan sınırlanması ya da işlerinin zorlaştırılması son derece elzemdir. Buradaki amacın güçlü bir devletin saldırısını önlemek ya da savaşta zafer elde etme şansını düşürmek olduğu iddia edilebilir. Bilindiği üzere, sert güç dengesi askeri dengenin sağlanmasıyla gerçekleşmektedir. Yani bu nedenle, askeri kapasitenin artırılmasına yönelik olarak zayıf tarafin çeşitli yöntemlerle (örneğin; askeri teknoloji transferi gibi) güçlendirilmesi gündeme gelmektedir. Buna karşın bir diğer yöntem yumuşak dengeleme seçeneğidir. Buradaki amaç; zayıf tarafın, güçlü tarafın askeri araçlarıyla doğrudan bir mücadele içerisine girmeden bu güçlerin kendisine karşı kullanımını zorlaştırmak olduğunu söylemek gerekir. Ancak her ne kadar yumuşak dengelemede; askeri olmayan unsurlar esasında hareket edilse de karşı tarafın askeri gücünü etkilemek amaçlar arasındandır. Somut olarak yumuşak dengeleme araçlarına birkaç örnek vermek gerekirse; bunlar, ekonomik açıdan gücünü artırmak ve diplomatik oyalama taktikleri veya rakip ittifaka katılma ihtimalinin karşı tarafa sezdirilmesi olarak dile getirilebilir (Pape, 2005: 36).

Pape, yumuşak güç ile ilgili olarak dört stratejiden bahsetmektedir. Birincisi; teritoryal bağlamda karşı tarafı geri çevirmektir. Genellikle güçlü devletlerin kara, deniz ve hava kuvvetleri için teritoryal bağlamda üçüncü tarafların alanlarından geçiş konusunda onlardan yararlandıkları 
görülmektedir. İşte bu geçişin geri çevrilmesi veya engellenmesi güçlü devletlerin savaş kabiliyetlerini kısıtlayacak ve lojistik maliyetlerini artıracak etkiler doğuracaktır. İkincisi, diplomatik oyalama taktikleri olarak ifade edilebilir. Güçlü devletler de diplomatik kuralları ve uygulamaları dikkate almak zorunda kalmaktadırlar. Bu ise zayıf tarafın diplomasi aracılığıyla uluslararası kurumları ve diplomatik manevraları devreye sokarak güçlü tarafın sürpriz bir saldırı yapmasına engel olmaktadır ve savaş planlarının uygulanmasını geciktirmektedir. Ayrıca güçlü devlet bir demokratik devlet ise; o devlet içerisinde bu süreçte iç muhalefetin de devreye girmesine ortam hazırlayabilir (Pape, 2005: 36-37).

Üçüncü strateji, diğer iki stratejiden farklı olarak iç dengelemeye başvurmaktadır. Yani ekonomik bakımdan devletin kendisini güçlendirmesidir. Genellikle askeri açıdan güçlü olan devletlerin ekonomik bakımdan da güçlerinin oldukları ve bunun askeri kapasitelerine yansımaları olduğu görülmektedir. $\mathrm{Bu}$ nedenle dengelemenin etkili bir şekilde sağlanabilmesi açısından zayıf tarafın ekonomik gücünü artırması önemlidir. Bölgesel ticaret blokları oluşturmak ve bu yapıya üye olmayan devletleri bu ticari yapıdan uzak tutmak yapılabilecek bu tip uygulamalardan birisidir. Böyle bir yapıdan uzak kalan güçlü devlet ekonomik açıdan zarar görecektir. Dördüncü strateji; dengelemeye yönelik kararlılık sinyallerinin karşı tarafa ulaştırılmasıdır. İkincil düzeydeki güçlerin güçlü tarafa karşı kolektif bir dengelemenin kurulmasına yönelik endişeleri bulunmaktadır. Bu noktada yumuşak dengeleme gerek saldırganı doğrudan sınırlandırma bağlamında gerekse karşılıklı olarak dengelemenin kurulabilmesi bağlamında işlev görecektir. Ayrıca daha önce dile getirilen stratejilerin diğer devletler nezdinde de karşılık bulması endişelerin ortadan kalkmasına yardımcı olarak kolektif bir dengenin oluşturulmasına katkı sunacaktır. Yumuşak dengelemede aslolan doğrudan güçlü devleti zorlamak yerine güçlü devletin geleceğe dair hırslarına karşı direnç sinyallerini gönderebilmektir. Böylece yumuşak dengeleme hem karşı tarafı sınırlandırma hem de daha çok devletin dengeleme koalisyonuna katılmasını sınırlandırma işlevi görecektir. (Pape, 2005: 37).

Aslında yumuşak dengeleme şeklinde adlandırılan kavram, Waltz'ın yapısalcı bir şekilde oluşturduğu güç dengesi teorisi ile Walt'ın tehdit dengesi olarak ifade ettiği teorinin bir sentezi biçiminde okunabilir. Her iki teori de dengenin kurulması ile potansiyel hegemonun denetlenmesi amacına yöneliktir (Brooks ve Wohlforth, 2005: 78).

Walt ise; yumuşak dengeleme dışında güç dengesi kapsamında bir diğer önemli konu başlığı olan peşine takılma (bandwagoning ${ }^{3}$ ) davranışına dair önemli birtakım açıklamalar yapmıştır. Walt, dengeleme ve peşine takılmanın tehditlere karşı verilebilecek daha doğru tepkiler olduğunu belirtmekte ve bu bağlamda dört unsurun etkisinden söz etmektedir. Birinci unsur, bir devletin toplam güç kaynaklarıdır. Yani devletlerin toplam güç kaynakları ya da kapasitesi ne kadar büyük olursa

\footnotetext{
${ }^{3}$ Bandwagoning teriminin Türkçe olarak tam karşılığı olmadığı için ve özellikle de tek kelime ile Uluslararası İlişkiler disiplini bağlamında terimleştirilmesi pek mümkün olmadığı için burada peşine takılma şeklinde Türkçeleştirilmiş̧tir. Zayıf devletin güçlü devletin safına geçtiği, güçlü devletin yanında yer alarak güvenliğini ve çıkarlarını koruma amacı olarak ifade edilebilecek söz konusu terim bu yüzden peşine takılma şeklinde özetlenmiştir.
} 
tehditlere karşı vereceği cevap o derece etkili olacaktır. İkinci unsur yakınlık durumudur. Çünkü yakın çevredeki devletlerden gelen tehditlerin boyutu daha ciddi boyutta olmaktadır. Üçüncüsü, saldırganlık bağlamındaki güç kapasitesidir. Çünkü saldırı gücü yüksek olan devlet diğer devletlere ya da devletler grubuna karşı avantajıdır. Dördüncü unsur, saldırgan niyetlerdir. Saldırgan bir devlet görüntüsü, diğer devletler nezdinde kendisine karşı bir dengelemeyi teşvik edici bir etkide bulunabilir. (Walt, 1985: 912).

Walt, peşine takılma politikasının geçerli olduğu bir dünyanın güç dengesine göre daha rekabetçi bir ortam sunduğundan bahsetmektedir. Bu durumda eğer devletler en güçlü ya da en fazla tehdit edici konumdaki devletle ittifak yapma tercihinde bulunursa; o zaman güçlü devletler güçlü veya potansiyel olarak tehlikeli göründüklerinde ödüllendirilecekleri söylenebilir. Uluslararası alandaki rekabetin daha yoğun olmasının nedeni ise; alınacak tek bir yenilginin dahi yenilgiyi alan taraf açısından mücadelenin kaybedilmesine yol açma ihtimalidir. Ayrıca devlet adamlarının güç politikalarına yönelmeleri daha yaygın bir davranış olacaktır. Çünkü uluslararası alandaki anlaşmazlıklarda karşı tarafın kazanma ihtimalinden korkulması ve dengenin sağlanamayabileceği endişesi devletlerin güç politikalarına yönelmesini tetiklemektedir (Walt, 1985: 14).

Diğer taraftan literatüre bakıldığında, ağırlığın dengelemeden yana olduğu buna karşın peşine takılma politikasının geri planda kaldığı görülmektedir. Aradaki farka değinmek gerekirse; dar bir çerçevede, dengeleme ile üstün konumdaki gücün dengelenmesi kastedilirken; buna karşın, peşine takılma ile güçlü tarafın yanında yer alma davranışı kastedilmektedir (Danilovic, 2002: 74).

Ayrıca güç dengesini aktarırken dış yardım konusuna ve nüfuz elde etme girişimlerine değinilmeden yapılacak bir analiz eksik kalacaktır. Dış yardım ya da uluslararası rüşvet şeklinde adlandırılabilecek politika şu şekilde işlemektedir. Bir devlet, ekonomik ya da askeri yardımda bulunarak etkili bir ittifakı oluşturabilir. Aslında dış yardım yapılan devletin dış yardımı sunan devlete karşı bir çeşit minnet duygusu hissederek ona göre diğer devlete bağımlı olması olarak bu politika aktarılabilir. Böylece ittifakların şekillenmesinde bu politika önemli bir rol oynayabilir (Walt, 1985: 27).

Nüfuz elde etme politikası ise; aslında bazı manipülatif araçları kapsamaktadır. Örneğin; sadakat bakımından sorunlu olan resmi görevliler aracılığıyla iki devlet arasında bir yakınlaşma sağlanabilir. Lobicilik faaliyetleri yürütülerek kamuoyu algısı ve uygulanan politikalara etki edilerek potansiyel bir müttefik imajı çizilebilir. Bunun dışında dış propaganda yoluyla elitlerin ve kitlelerin tutumları üzerinde etkili olmaya çalışılabilir (Walt, 1985: 30).

Burada yer verilen bilgiler ve örneklendirmeler genellikle Soğuk Savaş dönemine hitap etmektedir. Ancak Soğuk Savaş sonrası dönemde de her ne kadar Güç Dengesi Teorisi ve güç dengesi terimi bir ilgi kaybına uğrasa da halen belirli olguları ve dönemleri analiz ederken kavramsal ve teorik temel sağlama işlevini sürdürebilmektedir. Bu nedenle Soğuk Savaş dönemine dair yapılan 
analizlerden bazılarının belirli olaylar nezdinde geçerliliğini sürdürdüğünü iddia etmek mümkündür. Ancak bu görüşe karşı çıkan idealist ve liberal bir perspektif de karşı argümanlarını ileri sürmüştür.

Bu nedenle, 1990'lı yıllarda dünyanın daha barışçıl bir hale geldiğinden ve Realizmin varlık sebebini yitirdiğinden söz eden pek çok uzman ve akademisyen olmuştur. Bu çerçevede Soğuk Savaş'ın sona ermesi ile uluslararası politikada bir dönüşüm yaşandığı argümanı da ileri sürülmüş̧ür. Ayrıca ekonomik bağlamda küreselleşmenin devletleri sınırlandırıcı etkilerinden bahsedilmiştir. Aynı şekilde uluslararası alanda işbirliği ve bilginin küreselleşmesine dair iyimser yorumlar da yapılmıştır. Hatta demokrasinin yayılmasına değinilmiş ve demokrasilerin kendi aralarında savaşmadıkları belirtilerek adeta tarihin sonuna gelindiği tezi dahi ileri sürülebilmiştir. Bunun dışında, uluslararası kurumların büyük güçleri sınırlayıcı etkilerinin olabileceği ve onların hukukun üstünlüğüne uymalarını sağlayarak hareket edecekleri de yapılan analizler arasında yer almaktadır (Mearsheimer, 2013: 91).

Fakat 11 Eylül sonrasında bu bakış açısının büyük oranda değiştiği söylenebilir. Ayrıca Realizmin tekrar su yüzüne çıkması mümkün olmuştur. Şüphesiz bunda bazı gelişmelerin ve olguların varlığı etkili olmuştur. Örneğin; milliyetçiliğin hala güçlü bir figür olması ve Batı Avrupa'da dahi ekonomik bütünleşmeye karşın devletin varlığını sürdürmesine değinilebilir. Aynı şekilde askeri gücün dünya politikasındaki öneminin korunduğunu da belirtmek gerekir. Diğer taraftan, İran, KDHC, Hindistan ve Pakistan'la birlikte nükleer silahların yayılması meselesi gündemdeki yerini korumaktadır. Buna ek olarak Çin'in yükselişi ve ABD ve Çin arasındaki olası rekabet de gözden kaçırılmaması gereken önemli gelişmelerdendir. Bu durumda dünyanın hala tehlikeli bir yer olduğu argümanını savunmak mümkündür. Devletlerin bu açıdan varlıklarını sürdürme konusundaki endişelerinin devam ettiğini hatırlatmak gerekir. Böylece güç dengesi de önemini korumaktadır. $\mathrm{Bu}$ anlamda uluslararası politikanın daima güç politikalarıyla özdeş olarak algılanması çok yanlış bir çıkarım olmayacaktır (Mearsheimer, 2013: 91).

Bu çerçevede Birleşmiş Milletlerin de sadece Soğuk Savaş döneminde değil aynı zamanda Soğuk Savaş sonrasında da güç dengesi politikaları bakımından araçsallaştırıldığı görülmektedir. Örneğin; BM Güvenlik Konseyi’ndeki veto davranışları ve eğilimleri bu kapsamda ele alınabilir. Ayrıca devletlerin Genel Kurul'da etkili olmaya çalışarak normatif bir etki yaratma çabaları ve uluslararası kamuoyu ve büyük devletleri etkileme çabaları da yine bu noktada dile getirilebilecek örneklerdendir. Bu nedenle Birleşmiş Milletler ve güç dengesi arasındaki ilişkiye dair birtakım gerekli açıklamaların yapılması elzemdir.

Ancak söz konusu açıklamalara geçmeden önce bu bölüm itibariyle bazı önemli noktaların altını çizmek gerekmektedir. $\mathrm{Bu}$ açıdan öncelikle belirtmek gerekir ki; güç faktörü aktarılan açıklamalar ve örnek olaylar temelinde uluslararası ilişkiler ve uluslararası sistem düzeyinde daima dikkate alınması gereken bir unsurdur. Bu bakımdan, Realizmin ve Güç Dengesi Teorisinin önemli bir teorik ve kavramsal çerçeve sunduğu söylenebilir. Burada rekabet, göreceli çıkarlar, devletlerin 
uluslararası sistemdeki merkezi aktör rolleri, savaş-çatışma olguları ve uluslararası sistemin anarşik yapısı gibi faktörlerin söz konusu teorik bakış açısına temel oluşturduğunu ifade etmek gerekir. Ayrıca BM gibi hükümetler arası kuruluşlar ve diğer uluslararası örgütler açısından da güç faktörünün dikkate alındığını ve devletler tarafindan bu örgütlerin de birer güç dengesi aracı olarak görüldüğünü ve bu kapsamda kullanıldıklarını hatırlatmak gerekir.

Fakat sadece Realizm ve Güç Dengesi Teorisinin argümanları ve varsayımları temelinde uluslararası ilişkileri ve uluslararası sistemi analiz etmek mümkün değildir. Bu açıdan, örneğin; Liberal teori kurumsal mekanizmaların gücü ve etkisi, karşılıklı bağımlılık, uluslararası hukuk ve uluslararası düzeydeki normlar ve mutlak çıkarlar gibi bazı unsurlarla uluslararası ilişkileri ve uluslararası sistemi farklı bir perspektiften analiz etmektedir. Diğer tafaftan Dünya Sistemleri Yaklaşımı ise; ekonomi ve politikayı sentezleyerek "sınıf temelli bakış açısını" uluslararası düzeye taşıyarak güç unsuruna farklı bir açıdan yaklaşmaktadır. Bu nedenle farklı teorik yaklaşımlar ile uluslararası sistemi ve uluslararası ilişkileri Güç Dengesi Teorisi perspektifinden farklı bir şekilde başka argümanlar temelinde analiz etmek mümkündür. Ancak güç unsurunun uluslararası ilişkilerdeki ve uluslararası sistemdeki merkezi önemine atfen bazı alanlar, aktörler ve unsurlar temelinde güç dengesinin teorik ve kavramsal çerçeve sunduğu belirtilebilir. Bu kapsamda Birleşmiş Milletler örgütünün belirtilen hususlar 1şığında üzerinde durulabilecek bir unsur olması nedeniyle güç dengesi perspektifinden bir analiz yapılması gerektiği iddia edilebilir.

\section{Bir Güç Dengesi Aracı Olarak Birleşmiş Milletler}

I. Dünya Savaşı'nın galipleri MC ile birlikte daha sakin bir dönemin geçirilmesi ve irrasyonel bağlamda yıkıcı savaşlardan uzak durulması gerektiğini ileri sürmüştür. Benzer bir düşüncenin II. Dünya Savaşı'nın galipleri bakımından da paylaşıldığı söylenebilir. Ayrıca saldırganlığa ve barışa yönelik olan tehditlere güçlü bir şekilde direnç gösterilmesi açısından bir Güvenlik Konseyi figürü üzerinde durulmuştur. Her iki durum için de amacın barışın ve istikrarın sağlanması olduğu görülmektedir (Latif, 2000: 25-26). Ancak BM'nin MC'ye göre daha kompleks ve derin bir yapıy1 içerdiğini vurgulamak gerekir.

Bu bağlamda, II. Dünya Savaşı'nın ardından büyük güçler tarafından I. Dünya Savaşı sonrasındaki savaş sonrası düzenlemelerin doğurduğu sonuçlardan dersler çıkarılarak Birleşmiş Milletler örgütü ve Bretton Woods kurumları odağında bir düzen inşa edildiği görülmektedir. Ayrıca buradaki çok taraflı sistemin kolektif bir yapıya dayandığını belirtmek gerekir. Bunun dışında BM'nin rolünün pek çok alan açısından geçerli olduğu söylenebilir. Örneğin; BM, jeopolitik ve jeoekonomik düzenlerle ilişkili olduğu gibi aynı şekilde küresel düzeyde çevre düzeni ve insani meseleler konusundaki düzenle de ilişkilidir. Bu çeşitli alanlardaki düzenlerin hassas bir yapıya sahip olduklarını hatırlatmak gerekir. $\mathrm{Bu}$ hassasiyeti tetikleyen nedenlerden bazıları milliyetçilik ve ticaret yani ekonomi unsuru olarak ifade edilebilir (Rudd, 2016: 4-5). 
Bu çerçevede BM büyük güçler arasındaki bir uzlaşının ya da II. Dünya Savaşı'nın galip güçlerinin bir yansıması şeklinde ele alındığında; (Lim, 2007: 308) daimi üyelerin sahip olduğu veto hakkı ile aslında devletlerin egemen eşitlik ilkesiyle örtüşmeyen bir yapının ortaya çıkmadığı iddia edilebilir. Yani burada veto gücü bütün devletlerin egemen eşitliğini koruyan bir güç dengesini sağlayan bir faktör olarak görülmektedir. Ayrıca bu noktada BM'nin MC'nin bir anlamda uzantısı şeklinde nitelendirilebileceğini de hatırlatmak gerekir. Çünkü benzer şekilde MC de uluslararası alanda bir düzenleyici rol üstlenme iddiasındaydı. Yine bu kapsamda MC'nin kuruluş sürecinde dile getirilen Wilson ilkeleri arasında yer alan ve MC'nin geçmişe göre önemli bir farkını ortaya koyan self determinasyon ilkesine de değinilebilir. Zira bu ilke ile insanların ve bölgelerin artık büyük güç siyasetinin bir unsuru olmaktan çıkarılacağı kastedilmekteydi. Söz konusu ilkenin BM tarafından da benimsendiği bilinmektedir. Bu noktada veto gücünün egemen eşitlik ilkesiyle çelişmeyebileceği iddiası öne sürülebilir. Çünkü BM Antlaşması'nda belirtilen toprak bütünlüğünün korunacağı ifadesi ile olası bir olumsuz durumun önüne geçilmeye çalışılmıştır (Lim, 2007: 314). Ancak hem MC hem de BM döneminde bu ilke büyük güçler tarafından pek çok kez ihlal edilmiş ve normatif düzeyde ortaya konan irade reel-politik koşullarda geçerlilik kazanamamıştır.

Zaten BM'nin örgütsel bağlamda planlanması ve düzenlenmesi büyük güçler tarafından yapılmıştır. Sadece son aşamada San Francisco Konferansı sırasında diğer devletlerin de sürece katıldığ1 görülmektedir. Bu nedenle örgütün kuruluş amacının savaşın kazanan taraflarının güç dengesini sağlamak adına kurumsal bir yapı oluşturma arzusu olarak tanımlamak mümkündür. Her ne kadar bu tip bir dayatmacı anlayışla örgüt kurulsa da kurucuları kendilerini özgür ve demokratik bir dünyayı temsil ettikleri şeklinde açıklamaktadırlar (Duchêne, 2008: 57). Bu argüman ise; BM'nin antidemokratik yapısına bir meşruiyet kazandırma girişimi olarak okunabilir.

$\mathrm{Bu}$ çerçevede uluslararası anlaşmalara bakıldığında; devletlerin kendi aralarında belirli konular açısından bir uzlaşmanın sağlanması için oldukça farklı konular ekseninde ve bazen de çatışan çıkarlarla uğraşılarak ortak bir noktaya varılmaya çalışıldığı görülmektedir. Bu açıdan BM'nin durumu da çok farklı değildir. Yani II. Dünya Savaşı sonrasında büyük güçlerin sahip oldukları farklı görüşlere karşın uluslararası alanda istikrarın sağlanması için ve yeni bir uluslararası rejimin oluşturulması için uzlaşmaya varmaları anlaşılabilir bir durumdur (Shraideh, 2017: 136). Aslında burada büyük güçlerin istikrar ve uluslararası rejimden anladıkları kendi çıkarları açısından en uygun yapının ortaya çıkması ve güç bakımından diğer büyük güçlerin dengeyi bozmaması için gayret gösterdikleri tespitini yapmak çok yanlış olmayacaktır.

$\mathrm{Bu}$ noktada BM'nin uluslararası sistemdeki ve oluşturulan yapısal düzenlerdeki rolü dikkate alındığında, bazı olumsuz sonuçlarla karşılaşılabileceğini iddia etmek mümkündür. Bu açıdan BM'nin sistemden çıkarılması mevcut yapının bir denge kaybına uğramasına neden olabilir. Böylece uluslararası ilişkilerde BM sonrasında bir boşluk meydana gelebileceği iddia edilebilir. Ancak tarihi gelişmelere bakıldığında, bu tip bir boşluğun yerinin kolayca doldurulabileceği görülmektedir. 
Örneğin; I. Dünya Savaşı sonrasında oluşturulan düzenin çökmesi sonrasında 1939'da başlayan II. Dünya Savaşı bu bağlamda ele alınabilir (Rudd, 2016: 5).

$\mathrm{Bu}$ kapsamda, eğer mevcut sistemde XIX. yüzyıl Avrupası'ndaki koşullara benzer bir anlayışın geçerli olduğu kabul edilirse; söz konusu kolektif güvenlik sisteminin sonsuza dek süreceğini düşünmek pek mümkün değildir. Lim ise; bu noktada mevcut kolektif güvenlik sisteminin XIX. yüzyıldaki Avrupa'da var olan güç dengesi sistemine benzer olduğunu düşünmektedir. Fakat sistemin kullanım ve amaçlar (güvenlik ve istikrar gibi) bakımından ömrünü tamamladığı görüşüne katılmamaktadır. Lim, BM Antlaşması'nın da ideallerin gerçekleştirilmesi bağlamında gücü sınırlandırmak ya da inkâr etmek yerine gücün ön plana alınarak işlevselliğinden yararlanılması gerektiğini ortaya koyan bir anlayışı benimsediğini ayrıca ifade etmektedir (Lim, 2007: 328). Lim'in bakış açısından güç siyaseti ve güç dengesi anlayışı reel-politik koşullar ve sistemdeki güç dağılımı göz önüne alındığında; sistemde istikrarın, barışın ve güvenliğin sağlanması için gereklidir. Ayrıca pek çok kişinin sorguladığı kolektif güvenlik sisteminin sürekliliği konusunda da mevcut koşullarda bir değişim ihtimali görmediğinden BM sisteminin şu anki haliyle devam edeceği görüşündedir.

Young ise; Birleşmiş Milletler'in uluslararası alanda oynadığı role atfen örgütü altı maddede farklı nitelendirmelere tabi tutarak sınıflandırmaktadır. Buna göre; ilk olarak BM, uluslararası sistemde var olan güç ilişkilerini düzenleyici bir araç olarak değerlendirilebilir. İkincisi, sistemdeki büyük güçler arasında yapılan anlaşmanın bir etki unsuru biçiminde algılanabilir. Üçüncüsü, siyasal değişimin gerçekleştirilebilmesi için bir araç olarak görülebilir. Dördüncüsü, dünya politikasında partizan çıkarların bir aracı biçiminde nitelendirilebilir. Beşincisi, bir norm oluşturma birimi ya da kolektif düzeyde meşrulaştırmanın ${ }^{4}$ sağlanmasında bir kaynak işlevi gören bir düzenek olarak değerlendirilebilir. Son olarak, devletler ve ulus devletler açısından uzun vadeli gelişmenin sağlanmasında bir yardımcı unsur şeklinde tanımlanabilir (Young, 1968: 903). Görüldügü üzere Young da örgütün güç ve güç dengesi ilişkisini ortaya koyan unsurlardan bahsetmektedir.

Ancak tüm bu aktarılanlara karşın güçlü devletlere yönelik olarak Afrika, Asya ve Latin Amerika bölgelerinde bir direnç gösterildiğini de belirtmek gerekir. Bu kapsamda öncelikle Latin Amerika ülkelerinin Soğuk Savaş’ın ilk dönemlerindeki pozisyonlarına bakıldığında, bu ülkelerin genel olarak ABD'yi desteklediklerini söylemek mümkündür. Buna karşın; 1959'daki Küba Devrimi sonrasında bu tablonun ciddi bir şekilde değiştiği gözlemlenmektedir. Bu noktada belirtmek gerekir ki; bütün bölge devletleri sömürge karşıtı bir tutum içerisindedirler. Ayrıca bu ülkelerin bazı durumlar dikkate alındığında, görece az gelişmiş ülkeler grubuna dâhil oldukları söylenebilir. Her ne kadar bu devletlerin bazı karşılıklı savunma düzenlemelerine taraf olduklarına atfen tam anlamıyla tarafsız devletler olarak nitelendirilmesi mümkün olmasa da bazılarının Bağlantısızlar Hareketi içerisinde yer aldıkları ve BM’nin Soğuk Savaş dikkate alındığında daha 1lımlı bir seyir izlemesine katkı sundukları

\footnotetext{
${ }^{4}$ Young, çalışmasında collective legitimization/kolektif meşrulaştırma'nın Claude'a ait bir terim olduğunu
} belirtmektedir. 
unutulmamalıdır. Birçok Afro-Avrasya bölgesinde yer alan ülke Bağlantısızlar Hareketi içerisinde yer almaktadır. Bu ülkeler, BM'nin zirve toplantıları öncesinde bir araya gelmektedir. Bu hareketin BM Genel Kurulu'ndaki yansıması olarak değerlendirilebilecek 77'ler Grubu'nun köklerinin UNCTAD toplantılarına dayandığını da belirtmek gerekir. Bu grup üçüncü dünya olarak nitelendirilen ülkelerin gelişmelerini koordine etmek amaciyla oluşturulmuştur (Bailey ve Daws, 1995: 42-45).

$\mathrm{Bu}$ noktada Bağlantısızlar Hareketi'nin uluslararası politikada Soğuk Savaş’ın yaşandığı iki kutuplu bir sistemde üçüncü bir yolun mümkün olduğunu göstermesinin oldukça önemli olduğunu belirtmek gerekir. Aslında bu hareket içerisinde yer alan devletlerin de uluslararası politikada var olan iki blok arasındaki güç dengesine oluşturdukları birlik ile bir anlamda katkı sundukları söylenebilir. Yani Bağlantısızlar Hareketi bazı dönemlerde ve bazı durumlarda güç dengesinde yaşanabilecek bir aksama ya da bozulmayı frenleyici bir etkide bulunmuştur. BM Genel Kurulu'ndaki faaliyetleri de aynı kapsamda değerlendirilebilir. Zira Bağlantısızlar Hareketi, BM Genel Kurulu'nda sahip olduğu geniş üye sayısı ile uluslararası politikaya ve uluslararası ilişkilere etki etme şansı elde etmiştir.

Afro-Asya ülkeler grubu açısından ilk olarak 1955 yılındaki Bandung Konferansı'nın (Bağlantısızlar Hareketi'nin ilk toplantısı) önemli bir başlangıç noktası teşkil ettiği aşikâr bir noktadır. $\mathrm{Bu}$ ülkeler, hem askeri bakımdan hem de ekonomik bakımdan gelişmiş ülkelere göre oldukça geridedir. Gerek tarımsal veriler; gerekse ticari ve diğer ekonomik veriler ışığında söz konusu ülkelerin oldukça sınırlı imkânlara sahip oldukları görülmektedir. Nitekim eğitim ve sağlık hizmetlerinin durumu da çok farklı değildir. Hatta bu ülkelerin bazılarının devlet yapısı açısından ilkel oldukları dahi iddia edilebilir. Fakat bu devletlerin BM'de yani Genel Kurul'da birlikte hareket ettiklerinde tüm bu olumsuz özellikleri bertaraf edebilme şansı elde ettikleri söylenebilir. Afro-Asya grubu kendi içerisinde daima bir bütünlük sergilemese de ya da tam olarak uzlaşmaya varılamasa da genel olarak sömürgecilik ve ırkçılık konusunda bir bütünlüğün ve uzlaşının sağlanarak sağlam bir ortak iradenin ortaya konulmasını sağlamıştır. Örneğin; Filistin meselesi, az gelişmiş ülkelere yapılan çok taraflı yardım programları ve Soğuk Savaş döneminde tarafsızlığın sağlanmasına yönelik olarak tutarlı bir birliktelikten söz edilebilir (Bailey ve Daws, 1995: 43).

$\mathrm{Bu}$ nedenle, sömürgelerin bağımsızlıklarını elde etmesi ve diğer bağımlı bölgelerin self determinasyon haklarını elde ederek BM üyesi olmaları BM açısından dengelerin değişmesini etkileyen önemli bir faktör olmuştur. Çünkü 1961 sonrası döneme bakıldığında Afro-Asya ülkeler grubunun Genel Kurul'da karar alınabilmesi için gerekli 2/3 nitelikli çoğunluğun elde edilmesinde oldukça belirleyici bir rol oynamaya başladıkları görülmektedir (Bailey ve Daws, 1995: 43).

Aktarılan hususlar dikkate alındığında, Afro-Asya grubunun dahi var olan tüm olumsuz özelliklerine karşın bir araya geldiklerinde literatürde yumuşak dengeleme şeklinde adlandırılan politikayı izleyerek kendilerinden çok daha güçlü devletlere karşı dahi görece bazı alanlarda olumlu kazanımlar elde etmeyi başarabilmişlerdir. Elbette bu politikanın izlenebilmesinde BM ve Genel Kurul 
oldukça önemli bir işlev üstlenmiştir. Bu nedenle bir kez daha BM'nin güç dengesi teorisi açısından önemli bir uygulama sahası olduğu görülmektedir.

$\mathrm{Bu}$ bağlamda, hem orta güçteki devletler bakımından hem de küçük güçler bakımından seslerini yeterince duyuramadıkları ya da görmezden gelindiklerine dair bir şikâyet söz konusu olmuştur. Aslında bu sorunun köklerinin San Francisco Konferansı'na yani BM'nin kuruluş sürecindeki son aşamada kaydedilen gelişmelere kadar uzandığı söylenebilir. Çünkü bu konferansta oy birliği konusunda tartışmalar yapılmış ve küçük güçlerin istekleri karşılanmamıştır. Böylece büyük güçlerin baskın olduğu sistem ortaya çıkmıştır. Her ne kadar bu sistemin uluslararası alanda barış ve güvenliğin sağlanmasına katkı sunacağı gerekçesi ileri sürülse de uluslararası alanda fikir birliğine varılmasına engel olduğu da kabul edilmelidir (Baehr ve Gordenker, 2005: 151).

Öte yandan, savaş sırasında SSCB, ABD ve Britanya arasında Mihver grubuna karşı kurulan bağın savaşın kazanılması sonrasında çözüldüğü görülmektedir. Daha sonra bilindiği üzere Soğuk Savaş süreci yaşanmıştır. Böylece uluslararası alanda barış ve güvenlik konusunda işbirliği kurulamamıştır ve bu gelişmenin BM'nin etkinliğine de doğrudan etkileri olmuştur (Latif, 2000: 27). Bu noktada, Soğuk Savaş döneminde örgütün iki blok arasında yaşanan siyasal ve ekonomik rekabetin mücadele sahnesi haline geldiği söylenebilir.

Soğuk Savaş döneminde BM, büyük güçler tarafindan bir uzlaşma ya da mevcut gerginlikleri azaltmak amacına hizmet eden bir unsur olarak değerlendirilmemiş bunun yerine Soğuk Savaş için bir mücadele alanı olarak görülmüştür. Soğuk Savaş'ın oldukça hızlı bir şekilde gelişmesi II. Dünya Savaşı sonrasında genel bir barış uzlaşmasının ve antlaşmasının ortaya çıkaracağı bir güç dengesinin sağlanmasına imkân tanımamıştır. Bu nedenle BM'nin de söz konusu barış planının sağlanmasındaki rolü tam anlamıyla kurgulanamamıştır (Russell, 1970: 323).

Ancak Soğuk Savaş'ın sona ermesi ve SSCB'nin dağılması gibi gelişmelerle birlikte BM konusunda iyimser bir hava söz konusu olmuştur. Hatta BM'nin kuruluş döneminde tasarlandığ1 haline uygun bir şekilde performans gösterebileceği dahi iddia edilebilmiştir. Yine bu dönemde Irak'ın Kuveyt'e yönelik saldırganlığına kolektif düzeyde bir yanıt verilmesi BM'nin uluslararası alanda barışın ve güvenliğin korunması konusundaki rolüne ilişkin iyimser bir tablonun çizilmesine neden olmuştur. Öte yandan, Körfez Savaşı ile birlikte insani müdahalenin gündeme geldiği görülmektedir. Ayrıca BM'nin barış koruma operasyonlarına yönelik taleplerin de ciddi oranda arttı̆̆ gözlemlenmiştir. Aktarılan hususlar 1şığında BM'de köklü reform çabaları görülmüştür (Latif, 2000: 25).

Bu kapsamda, Soğuk Savaş döneminde bloklar arası rekabetin sonucu olarak karşılıklı vetolarla birlikte Güvenlik Konseyi’nin de işlevsiz bir görüntü çizdiği söylenebilir. Bu bakımdan güç istismarı ya da yasal zemin açısından Konsey'in çok fazla sorgulanma şansı olmamıştır. Fakat bu durumun Soğuk Savaş sonrasında değiştiği görülmektedir. Çünkü Rusya'nın ve Çin'in Batı ile 
aralarındaki rekabet ortadan kalkmış ve böylece 90'ların başında daimi üyeler arasındaki uyumsuzluk giderilerek daha etkin bir Konsey ortaya çıkmıştır (Gordon, 2014: 42). Bu dönemde Rusya'nın siyasal ve ekonomik açıdan köklü bir değişim ve dönüşüm geçirerek sosyalist sistemden liberal-kapitalist sisteme evrilmeye çalıştığını ve Çin'in de Mao sonrasında Deng ile başlayan kapitalist sistemle belirli ölçüde uyumun sağlanması adına yaptığı ekonomik bağlamdaki liberalleşme girişimleri ve DTÖ’ye üye olunmasını hatırlatmak gerekir. Özetle ifade etmek gerekirse; hem Rusya hem de Çin önemli bir değişim sürecinde Batı ile uzlaşmacı bir tavır takınmak durumunda kalmışlar ve bu da BM ve Konsey’e doğrudan yansımıştır. Böylece bu dönemde sanki güç dengesi BM ve Konsey bakımından Batı eksenine doğru kaymış gibi gözükmektedir.

Söz konusu dönemde oluşan olumlu havada 31 Ocak 1992 tarihinde BM Güvenlik Konseyi'nin gelecekte uluslararası alanda barışın ve güvenliğin korunması için Güvenlik Konseyi'nin sorumluluğuna karar vermek amacıyla hükümet başkanları düzeyinde yaptığı toplantı Soğuk Savaş sonrası BM'nin işlevselliği ve etkinliği bağlamında yapılan önemli gelişmelerden birisi olarak değerlendirilebilir. Bu toplantıya Genel Sekreter Boutros-Ghali de davet edilmiştir. Ayrıca Ghali'den BM'nin önleyici diplomasi, barış yapma ve barış koruma meselelerine ilişkin olarak örgütün kapasitesinin artırılabilmesi için neler yapılması gerektiği konusunda bir rapor hazırlaması talebi olmuştur. Öte yandan, Genel Sekreterliğin bahsi geçen konu başlıkları dışında çatışma sonrasında barış inşası konusunu da öncelikli olarak gündeme aldığı görülmektedir. Bu çerçevede Ghali, birbiriyle bağlantılı olarak BM'nin uluslararası politikada beş önemli rol üstlenmesi gerektiğini bildirmiştir. Bunlar; önleyici diplomasi, barışı güçlendirme, barış yapımı, barış koruma ve çatışma sonrasında barış inşası şeklinde ifade edilmiştir (Keskin, 2002: 274).

Diğer taraftan, 1996'dan itibaren Konsey'deki güç dengesinin tekrar değiştiği görülmektedir. Çünkü Rusya ve Çin, ABD ve Britanya'ya karşı itirazlarını yükseltmeye başlamış ve Fransa da Batı ekseninden farklı bir çizgi izlemeye başlamıştır. Ancak bu duruma karşın 2001'e kadar olan dönemde Konsey'in uluslararası hukuku veya yasal zemini kötüye kullandığına dair çok fazla bulgu elde edilememiştir. Buna karşın 11 Eylül 2001'de yaşanan saldırılardan sonra Konsey'deki denge yine değişmiştir (Gordon, 2014: 43). Bu dönemde Kosova konusunda yaşanan anlaşmazlığı da unutmamak gerekir. Daha sonra bilindiği üzere Irak konusunda Konsey'de yaşanan gerilim ve BM'nin otoritesinin sarsılması önemli bir dönüm noktası olmuştur. Ancak yine de ABD-İngiltere ikilisinin meşruiyet sorunu yaşamaları ve sahada da uzun vadede beklenenden daha çok mali ve askeri kayıplara uğramaları örgütün öneminin bir kez daha anlaşılmasını sağlamıştır. Böylece Irak konusundaki girişimlere izin vermeyen Fransa, Çin ve Rusya'nın vetosu dolaylı yollardan da olsa ABD ve İngiltere'nin bir kayıp yaşamalarına neden olmuştur.

$\mathrm{Bu}$ nedenle, uluslararası alanda güçlü devletlerin kuvvet kullanımını önlemek açısından BM'nin Güvenlik Konseyi onayına ihtiyaç duyulmaktadır ancak mevcut yapının değiştirilmesi pek mümkün değildir. Bu kapsamda yukarıda değinildiği üzere, ABD’nin ulusal çıkarlarını öne sürerek 
Güvenlik Konseyi onayı olmadan II. Körfez Savaşı'nda kuvvet kullanması ve BM'nin bu eyleme yönelik muhalefetini görmezden gelmesi ele alınabilir. Ayrıca bu savaş esnasında Genel Sekreter'in durumu da sorgulanmıştır. Çünkü BM Genel Sekreteri bu olayda güçlü bir devletin kuvvet kullanmasına karşı etkin bir müdahalede bulunamamıştır. Böylece bir kez daha örgütün etkisiz ve zayıf olduğu yönündeki eleştiriler tekrarlanmıştır (Lupu, 2006: 905).

$\mathrm{Bu}$ noktada tekrar vurgulamak gerekir ki; Güvenlik Konseyi'nin asli görevlerinden birisi uluslararası alanda barışın korunmasıdır. Ancak bu görevin son dönemde tam olarak yerine getirilemediği görülmektedir. Çünkü özellikle Rusya ve Batı arasında yaşanan rekabet Güvenlik Konseyi'nin bu anlamda etkinliğini azaltmaktadır (Sengupta, 2016). Suriye, Irak ve Kosova örnekleri göz önüne alındığında; Güvenlik Konseyi’nin veto nedeniyle gelişmelere müdahale edemediği ve kuruluş amacı olan uluslararası alanda barış ve güvenliğin korunması bakımından görevlerini yerine getiremediği görülmektedir. Bu nedenle dünya savaşlarının ana nedenlerinden birisi olan tek taraflılık eğiliminin devam ettiği ve dünya barışının sağlanması için gerekli olan uzlaşmanın ortaya konulamadığı anlaşılmaktadır (Shraideh, 2017: 138-139).

$\mathrm{Bu}$ açıdan, hala Realistlerin vurguladığı üzere devletler, kendi göreceli çıkarları ekseninde hareket etmektedir. Kolektif eylemler yerine tek taraflı eylemler tercih edilmekte bu da güç siyasetinin kendisine alan bulmasına imkân tanımaktadır. Bu yüzden daimi üyeler Suriye, Irak (II. Körfez Savaşı) ve Kosova meselelerini uluslararası alanda barışın korunması perspektifinden değerlendirmek yerine stratejik planlar ve jeopolitik çıkar hesapları ve rekabet unsurları temelinde değerlendirmektedirler. Örneğin; Suriye özelinde yaşanan ABD-Rusya rekabeti iki tarafın karşılıklı olarak bölgedeki güç dengesini kendi lehlerine çevirme ya da koruma mücadelesinin bir yansımasıdır. Böylece denilebilir ki; göreceli çıkarlar, rekabet ve güç dengesi büyük güçler başta olmak üzere devletler açısından hala önemini koruyan unsurlardır.

Göreceli çıkarların geçerli olduğu bir yaklaşımı benimseyen anlayışa göre, uluslararası ilişkiler sıfır toplamlı bir oyun mantığı içerisinde ele alınmaktadır. Bu nedenle bu mantığı kabul eden bir devlet açısından karşı tarafın gücünde ya da prestijinde meydana gelebilecek bir artış doğrudan kendi kaybı olarak değerlendirilmektedir. Böylece devletlerin, diğer devletlerin gücünü sınırlama çabası içerisinde oldukları söylenebilir. Bu perspektife göre hareket eden bir devlet işbirliğinin sağlayacağı çıkar ya da faydanın karşı tarafa da yarayacağı düşüncesiyle işbirliğinden kaçınmayı tercih edecektir. Bu noktada ayrıca söz konusu yaklaşımdan BM ve BM Güvenlik Konseyi konusunda yaşanan reform tartışmaları ve eleştiriler konusunda yararlanılabileceğini belirtmek gerekir (Pijovic, 2012: 33-34).

$\mathrm{Bu}$ kapsamda Güvenlik Konseyi’nde göreceli çıkarlar temelinde hareket edilerek güç ve prestijin korunmaya çalışıldığı ve veto gücünün de bu bağlamda araçsallaştırıldığını iddia etmek mümkündür. Çünkü daimi üyeler Konsey'de gündeme gelen veya tartışılan sorun bağlamında, sorunun hangi bölgede olduğuna ya da bölgenin ekonomik durumuna bakmamaktadır. Bunun yerine 
bölgenin/sorunun kendi açılarından nasıl bir önem taşıdığ 1 ve güç kapasitelerine nasıll bir yansıması olacağı perspektifinden bir değerlendirme yapılmaktadır (Pijovic, 2012: 39). Ayrıca BM Güvenlik Konseyi'nde beş daimi üyenin vetoyu istismar ettiklerinde yapılabilecek çok fazla bir şeyin olduğu söylenemez. Bu durumun değiştirilmesinin BM Antlaşması hükümleri göz önüne alındığında oldukça zor olduğu da aşikâr bir durumdur (Baehr ve Gordenker, 2005: 150).

Aktarılan hususları dikkate alarak uluslararası ilişkilerin ve uluslararası politikanın mevcut durumu değerlendirildiğinde; sistemin en güçlü devletlerinin olmadığı bir yap1 ya da bileşimle uluslararası alanda barış ve güvenliğin sağlanamayacağı anlaşılmaktadır. Bu nedenle, uluslararası alanda etkili kolektif eylemlerin ortaya konulabilmesi ve uluslararası alanda barış ve güvenliğin sağlanması bakımından sistemdeki büyük güçlere ihtiyaç duyulduğu söylenebilir (Shraideh, 2017: 140).

BM'nin mevcut durumunun güç ile ilişkisi göz önüne alındığında; Güvenlik Konseyi ile ilgili reform tartışmalarının da güç ve güç dengesi olguları dışında değerlendirilmesi pek mümkün değildir. Zaten reform konusunda gündeme getirilen üyeliğe ilişkin olarak ortak bir modelde uzlaşılmaması bu yargıyı doğrulayan bir gelişme olmuştur. Örneğin; Güvenlik Konseyi üyeliğini hedefleyen devletlerin bu çabalarının komşuları tarafından olumsuz algılanması göreceli çıkarlar ve Realist paradigmanın kuşkucu yaklaşımlarının bir yansımasıdır. Çünkü bu devletler rakiplerinin söz konusu üyeliği elde etmesi sonucunda prestijlerinin sarsılacağı ya da uluslararası alandaki önem dereceleri bakımından bir kayba uğrayacakları kaygısını taşımaktadırlar. Böylece sıfır toplamlı oyun mantığı yine gündeme gelmektedir. Elbette bu durum mevcut statükoda daimi üyelik ve bununla bağlantılı olarak veto hakk1 olan beş üye açısından pozisyonlarını korumalarına imkân sağlamaktadır (Pijovic, 2012: 39).

Sonuç olarak; BM'nin uluslararası sistemde önemli bir rolü olduğu aşikârdır. Bu kapsamda mevcut küresel jeopolitik düzene bakıldığında, üç önemli alanla karşılaşılmaktadır. Birincisi, büyük güçlerin hem kendi aralarında hem de diğer devletlerle kurdukları çeşitli alanlardaki ilişkiler bu bağlamda dile getirilebilir. $\mathrm{Bu}$ alanlar ile jeopolitik, askeri, diplomatik ve ittifak ilişkileri kastedilmektedir. İkinci olarak, devletler arasındaki yatay ilişkiler gündeme gelmektedir. Burada ise; büyük devletlerle kurulan müttefiklik ilişkileri ya da tarafsız devletlerin durumu ele alınmaktadır. Son olarak üçüncüsü; küresel ve bölgesel düzeyde faaliyet gösteren kuruluşlardan bahsedilebilir (Rudd, 2016: 4).

$\mathrm{Bu}$ noktada $\mathrm{BM}$ ve sivil toplum ilişkisine bir parantez açmak gerekir. Genel olarak Batılı güçlerin sivil toplumun BM ilişkilerine dâhil edilmesi taraftarı olduğu bilinmektedir. Bu durumun söz konusu güçlerin liberal politik kültürleri ile yakından ilgisi olduğu söylenebilir. Ancak aslında Batılı güçlerin bu yaklaşımının Kuzey'in STK'larının ulus ötesi ağlardaki baskın konumu düşünüldüğünde, durumun sadece liberal perspektifle değerlendirilmesi mümkün olmamaktadır. Örneğin, Batı ülkelerinin Güvenlik Konseyi’nin ve diğer uluslararası alanda etkili olan güç merkezlerinin 
demokratikleşmesine karşı olan olumsuz tutumlarının liberal perspektifle nasıl bağdaştırılabileceği soru işaretidir. Buna karşın; her ne kadar tam bir uzlaşı içerisinde olamasalar da yükselen güçlerin Konsey'de üye sayısının genişletilerek bir değişiklik yapılması konusunda olumlu bir yaklaşımı benimsediklerini belirtmek gerekir. Ayrıca bu noktada yükselen güçlerin BM-sivil toplum ilişkilerine aynı olumlu yaklaşımı benimsemediklerini hatırlatmak gerekir ki bu zaten beklenen bir durumdur. Çünkü bu devletler, sivil toplumun BM'de Batı perspektifinden hareket edeceği öngörüsünde bulunmaktadır (Thérien, 2015: 237).

BM ve uluslararası sistem arasındaki ilişkiyi ise; şu şekilde özetlemek mümkündür: Öncelikle, Birleşmiş Milletler; Genel Kurul'un ve Güvenlik Konseyi'nin faaliyetleri çerçevesinde uluslararası hukuka katkı sunmaktadır. Ayrıca Güvenlik Konseyi’nin kararlarının yaptırım gücü bir ulusal hükümetin kanunlarına benzer bir işlev görmektedir. Böylece örgütün bu organlar üzerinden bir meşruiyet aracı işlevi gördüğü aşikârdır. Öte yandan BM, gerek Genel Kurul çerçevesinde pek çok farklı bölgeden gelen ve farklı gelişmişlik seviyesinde olan devletin meydana getirdiği yapısıyla gerekse Güvenlik Konseyi bağlamında büyük güçlerin bir araya gelmelerini sağlayarak ve bir uzlaşıya varmaları bakımından bir platform imkânı sunarak diplomasi aracı rolü üstlenmektedir. Bunun dışında bağlı, ilgili ve ilişkili kuruluşları ile uluslararası çapta oldukça derin ve karmaşık bir ağ yapısına sahip olarak sistemik bir aktör işlevi gördüğünü göstermektedir. BM'nin söz konusu işlevleri dikkate alındığında denetleyici ve düzenleyici bir sistemik unsur olduğu iddia edilebilir.

Zaten Irak, Suriye, Libya ve Ukrayna gibi son dönemde yaşanan güncel olaylara bakıldığında BM'nin bahsi geçen rol ve işlevlerinin somut olarak yansımaları görülmektedir. Örneğin Güvenlik Konseyi'nde Irak konusunda bir uzlaşıya varılamaması ve bunun sonucunda yasal zeminin oluşturulamaması sonucunda ABD ve Birleşik Krallık açısından hem meşruiyet krizi yaşanmış hem de mali ve askeri kaynaklar bakımından olumsuz bir tablo ile karşılaşılmıştır. Irak'ta olduğu üzere aynı şekilde Libya, Suriye ve Ukrayna konusunda da üyelerin kendi perspektiflerinden bir durum değerlendirmesi yaptıkları ve karar alma süreçlerinde buna uygun olarak davrandıkları görülmektedir. Bu bakımdan meşruiyet sorunsalı ve BM'nin sistemik aktör rolü üyeler arasındaki güç politikalarından etkilenmiştir.

Diğer taraftan, BM'nin özellikle küçük devletler ve genel olarak da devletler açısından hem uluslararası politika hem de sistemik meselelerle ilgili olarak bilgi edinme bağlamında oldukça önemli bir rolü olduğunu belirtmek gerekir. Bu kapsamda BM ve IMF gibi hükümetler arası örgütlerin küçük ülkeler açısından önemli bir görev üstlendiği iddia edilebilir (Ataman, 2003: 44). Böylece BM'nin sistemin neredeyse tüm aktörlerine ulaşarak sistemik bir aktör rolünü yerine getirdiği görülmektedir.

Bir başka açıdan ise BM statükonun korunması bakımından da önem arz etmektedir. Çünkü BM, meşruiyet zemini sağlama, insani müdahaleler ve güvenlik meseleleri kapsamında gerçekleştirilen askeri müdahaleler ile sistemin aşırı uçlarının denetlenmesinde ve kontrol altına 
alınmasında sağladığı imkanlarla ve reform çabaları ve örgütün değişim ihtimalinin gündemde tutularak olası revizyonist güçlerin sistem içerisinde tutulmasını sağlamaya çalışması ile statükocu bir görüntü ortaya koymaktadır. Böylece güç dengesinin korunması ve sürdürülmesi açısından örgütün önemli bir sistemik rolü olduğu söylenebilir.

Ancak burada ayrıca belirtmek gerekir ki; uluslararası ilişkilerde düzen olgusu kendiliğinden ortaya çıkan bir durum değildir. Bu kapsamda son beş yüzyıla bakıldığında dört önemli denemenin yapıldığı görülmektedir. Bunlar 1648 (Westfalya Barışı); 1815 (Napolyon Savaşları sonrası); 1919 (I. Dünya Savaşı sona ermiş ve savaşı bitiren antlaşmalar imzalanmıştır. Ayrıca MC'ye yönelik çalışmalar yürütülmüştür.); ve 1945 (II. Dünya Savaşı'nın sona ermesi ve savaşı bitiren antlaşmalarla birlikte BM'nin kurulması.). İlk üç girişimin çok da başarılı olduğunu söylemek pek mümkün değildir. Dördüncü girişimin süreci ise henüz devam etmektedir. Burada, BM'nin kuruluşunda tek bir hegemonun baskın olduğu bir yapının olmadığını vurgulamak gerekir. Oysaki; önceki dönemlerde Roma gibi tek bir büyük gücün hakimiyetindeki bir düzen (Tarihte başka bir güç bunu başaramamıştır.) ya da birkaç büyük gücün uzlaşısıyla ortaya çıkan güç dengesi düzenleri oluşturulmuştur. Örneğin 1815-1914 arasındaki dönemde uygulanan Avrupa Uyumu bu çerçevede değerlendirilebilir (Rudd, 2016: 5). Son güncel örnek ise; BM Güvenlik Konseyi’nde oluşturulan güç dengesi eksenindeki yapının BM'nin ve uluslararası sistemin işleyişindeki rolü ile gözlemlenmektedir.

Söz konusu yapıya ilişkin olarak; Almanya ve Japonya gibi gelişmiş devletler ile Brezilya ve Hindistan gibi yükselen güçlerden bir reform talebi dile getirilmektedir. Buna karşın bu devletlerin bölgesel rakipleri (İtalya-Almanya; Pakistan-Hindistan; Arjantin-Brezilya) mevcut güç dengesi ve güç dağılımımın bozulacağından endişe ederek bu talebe itiraz etmektedir. Ayrıca önceden olduğu üzere orta güçteki devletler ile küçük devletler mevcut yapının daha eşit ve demokratik bir yapıya evrilmesi talebini öne sürmektedirler. Böylece devletlerin genel olarak BM'yi ve özel olarak ise BM Güvenlik Konseyi'ni güç açısından bir mücadele platformu olarak görmeye devam etmekte oldukları iddia edilebilir.

Diğer taraftan, Birleşmiş Milletler örgütü farklı teorik bakış açılarından farklı şekillerde ele alınabilir. Kimileri, BM'yi bir uzlaşı, barış ve dayanışma platformu olarak analiz edebilir. Ya da bir dünya devleti vizyonuna ulaşabilmek açısından BM geçirilmesi gerekli bir aşama olarak değerlendirilebilir. BM'nin uluslararası sistemde diplomasi, denetleme-düzenleme, uluslararası düzeyde norm oluşturma kapasitesi gibi işlevleri bu bağlamda dile getirilebilecek unsurlardandır. Fakat genel olarak uluslararası sistemin yapısı ve BM'nin yapısı göz önüne alındığında ağırlıklı olarak güç ilişkilerinin öne çıktığı görülmektedir. Bu nedenle BM'nin de bir güç dengesi politikası aracı olarak algılandığ1 ve kullanıldığı söylenebilir. Güvenlik Konseyi’ndeki ve Genel Kurul'daki karar verme süreçleri ve oy tercihleri ile daimi üyeliğe yönelik talepleri ve reform çabalarını bu kapsamda değerlendirmek mümkündür. Çalışmada da örnek olaylar ve BM'ye dair sunulan açıklamalar temelinde aktarıldığı üzere örgütün güç dengesi ile ilişkisi açık bir şekilde görülmektedir. Bu nedenle 
Güç Dengesi Teorisi'nin örgüt açısından açıklayıcı bir kavramsal araç olarak ele alınabileceğini iddia etmek mümkündür.

\section{Sonuç}

Güç Dengesi Teorisi, çalışmada elde edilen bulgular ve irdelenen örnek olaylar temelinde rekabet, göreceli çıkarlar, güç ilişkileri, uluslararası sistemin yapısı, devletler arasındaki güç dağılımı, sistemdeki güçlü devletlerin sayısı ve ittifaklar/bloklar arasındaki güç dağılımı gibi unsurlar ekseninde kısaca özetlenebilir. Güç dengesi olgusu ise; çalışmadan elde edilen çıkarsamalar neticesinde şu şekilde ifade edilebilir: Güç dengesi; birkaç devlet ya da ittifak grubu arasında aktörlerin kendi güç kapasitelerini artırmaya çalışmaları veya güç uygulama araçlarını çeşitlendirme girişimleri sonucunda uluslararası sistemde ortaya çıkan güç dağılımıdır.

Güç Dengesi Teorisi, ve güç dengesi olgusu; devletler düzeyinde ve Soğuk Savaş özelinde sıç̧a kullanılan önemli bir kavramsal ve teorik araç imkanı sunmaktadır. Ancak bu teorinin ve olgunun özellikle Soğuk Savaş sonrasında ve diğer aktörler temelinde geçerliliği sorgulanmaktadır ve eleştirilmektedir. Fakat çalışmada da sunulduğu üzere bazı unsurlar açısından hem Soğuk Savaş sonrasındaki gelişmeler hem de Birleşmiş Milletler gibi uluslararası örgütler dahi güç dengesi perspektifinden analiz edilebilir. Bu noktada güç dengesinin Birleşmiş Milletler açısından ve Soğuk Savaş sonrası dönemde neden ve nasıl uygun bir kavramsal ve teorik araç imkânı sunduğuna dair bazı önemli hususların altını çizmek gerekmektedir.

Soğuk Savaş sonrasında, oluşan iyimser havaya karşın; Çin ve Rusya'nın uluslararası politikada etkinliklerini artırmaları, yükselen güçler şeklinde nitelendirilen devletlerin sisteme yönelik olarak revizyonist talepleri, 11 Eylül saldırılarıyla birlikte devlet odaklı güvenlik politikalarının tekrar gündeme gelmesi, ve AB'nin bütünleşme çabalarının üyeler arasındaki rekabet ve ulusal çıkarlar nedeniyle istenen düzeye ulaşamaması gibi gelişmeler uluslararası ilişkiler ve uluslararası politika bağlamında güç dengesinin kendisine alan bulmasına olanak sağlamaktadır.

Öte yandan, Birleşmiş Milletler örgütü kurumsal ve yapısal bağlamda analiz edildiğinde açık bir şekilde kuruluşundan günümüze hep bir güç ilişkileri ağı içerisinde yer almıştır. Bu durum yalnızca Güvenlik Konseyi gibi son derece belirgin olan organlar üzerinden değil aynı zamanda diğer organlar ve ilişkili kurumlar ve sistem açısından da söz konusudur. Örneğin; Genel Kurul'da alınacak kararlara etki edebilmek için sadece güçlü devletler değil orta ve küçük devletler de çaba göstermişlerdir. Bağlantısızlar Hareketi'nin Genel Kurul'da kurduğu etkinlik bu anlamda dile getirilebilecek önemli bir örnektir.

Güvenlik Konseyi açısından bakıldığında ise; son dönemde Rusya'nın ve Çin'in ABD-Birleşik Krallık-Fransa üçlüsü ile sık sık karşı karşıya geldiği görülmektedir. Bu açıdan adeta yeni bir DoğuBatı karşıtlığı oluştuğu söylenebilir. Aslında Çin ve Rusya Konsey’de birlikte hareket ederek pek çok alanda rekabette olduğu Batı ile burada da güç dengesini sağlamaya çalışmaktadır. Bunun dışında 
daimi üyeler tekil olarak da kendi ulusal çıkarlarına ve jeopolitik-jeoekonomik bağlamda kendileri açısından en kazançlı olacak hamleye göre karar verme davranışı içerisindedirler. Örneğin; Irak ve Suriye konusundaki kararlar sırasındaki oylamalar bu kapsamda incelenebilir. ABD ve Birleşik Krallık açısından, Irak'a müdahale konusunda demokrasi, kötü yönetim, otokrasi ya da kitle imha silahları gibi meseleler öne sürülmüştür. Ancak burada öncelikle petrol kaynaklarına ulaşma amacı bulunmaktadır. İkinci olarak, Orta Doğu'da jeopolitik, jeoekonomik ve jeostratejik açıdan oldukça önemli olan bir ülkenin kontrol altına alınarak buradaki etkinliğin korunması ya da güçlendirilmesi bir diğer önemli etken olmuştur. Bu konuya Suriye özelinde bakıldığında ise; ABD’nin, Birleşik Krallık'ın ve Fransa'nın meseleye benzer şekilde demokrasi, insan hakları ve kitle imha silahları gibi argümanlarla yaklaştıkları görülmektedir. Ancak aslında amaç oldukça farklıdır. Yine ekonomik ve siyasal amaçlar ekseninde politikalar güdüldügünü tespit etmek mümkündür. Buna karşın Rusya ve Çin de Suriye meselesine benzer sebeplerle yaklaşmışlardır. Kısacası, bu iki somut örnekten de anlaşılacağı üzere BM Güvenlik Konseyi ana görevi olan uluslararası alanda barış ve güvenliğin korunmasını sağlamak yerine tekil olarak daimi üyelerin ekonomik ve siyasal beklentileri ve amaçları ekseninde güç politikalarında bir araç konumuna indirgenmektedir. Daimi üyeler mevcut güç dengesinin korunması ya da lehlerine bozulması için Konsey'i bir meşruiyet, politika ve diplomasi aracı olarak görmektedirler.

Ayrıca uluslararası sistemde mevcut güç dağılımına yönelik olarak revizyonist ve reformist talepleri olan Almanya, Japonya, Hindistan ve Brezilya gibi devletlerin de BM Güvenlik Konseyi daimi üyeliği talebinde bulunması Konsey'in ve örgütün devletler açısından güç dengesinin kendi lehlerine çevrilmesi bakımından önemli bir araç olarak görüldüğ̈̈ne işaret etmektedir. Bu açıdan Soğuk Savaş sonrasında da hala BM'nin güç dengesi politikaları ekseninde araçsallaştırıldığı görülmektedir.

$\mathrm{Bu}$ noktada, BM'nin uluslararası sistemde önemli bir rolünün olduğunu vurgulamak gerekir. $\mathrm{BM}$, neredeyse tüm devletleri bünyesinde barındırarak önemli bir diplomasi aracı olarak işlev görmektedir. Öte yandan, BM uluslararası alanda yaşanan ve sistemin istikrarını tehdit eden anlaşmazlıklar ve çatışmalar açısından Güvenlik Konseyi aracılığıyla düzenleyici ve denetleyici bir rol de üstlenmektedir. Bunun dışında ana organları, kendisine bağlı alt kuruluşları ve ilişkili olduğu kuruluşları sayesinde pek çok alanda faaliyet göstererek uluslararası sisteme etki edebilmektedir.

Ancak buna karşın; çalışmada elde edilen veriler ve bulgular 1şığında Birleşmiş Milletler'in bazı unsurlar temelinde sorunlu bir yapıya sahip olduğu ve yeterince etkinlik gösteremediği söylenebilir. Bu açıdan, BM'nin eşitlik, demokrasi, etkinlik, kapsayıcılık, sorun çözme becerisi ve otorite bağlamında sorun yaşadığını ifade etmek mümkündür. Eşitlik sorunu, Güvenlik Konseyi'nin yapısı ve görevleri bakımından; etkinlik sorunu, uluslararası politikada ana belirleyici aktör olamaması ve güçlü devletlerin politikaları nedeniyle prestij ve kurumsal güç kaybına uğraması bakımından dile getirilebilir. Ayrıca üyelere eşit ve adil bir ortam sağlayamadığı için kapsayıcılık konusunda ve 
uluslararası alanda anlaşmazlıkların ve çatışmaların çözümü bağlamındaki başarısızlığı ile sorun çözme becerisi konusunda yetersiz kalmaktadır. Son olarak otoritesinin güçlü devletler ve çatışma ve anlaşmazlıklar yaşayan taraflar söz konusu olduğunda yeterli düzeyde olmadığını belirtmek gerekir.

Söz konusu sorunların çözülmesi için ise; bazı hamleler ve değişiklikler yapılabilir. BM'nin eşitlik sorununun çözülmesi açısından BM Güvenlik Konseyi’nin yapısında değişiklik yapılmalıdır. Daimi üyelik sistemi ve veto gücü kaldırılarak, bölge ve güç dengeleri gözetilerek daha eşit ve dengeli bir yap1 oluşturulabilir. Ya da Güvenlik Konseyi lağvedilerek tek yetkili merci Genel Kurul olarak belirlenebilir. Bu yöntemlerle daha eşit ve adil bir yapının kurulması örgütün kapsayıcılık sorununu da ortadan kaldıracaktır. Böylece örgütün anti-demokratik yapısı bakımından dile getirilen eleştirilere de bir çözüm sunulmuş olacaktır. BM'nin sorun çözme becerisinin güçlendirilmesi için bağımsız ve uzman bir kurulun yürüteceği çalışmalar sonucunda elde edilen raporlar aracılığıyla anlaşmazlık ya da çatışma yaşayan tarafların uzlaşabileceği adil bir çözüm mekanizması kurularak bu alandaki sorunlar giderilebilir. Bunun dışında, BM'nin tarafların alınan kararlara uyması için siyasal ve ekonomik yaptırımları da gündemine alması ya da her iki tarafın da yararlanacağı ekonomik yardım paketleri gibi bazı uygulamalara yer vermesi de çözüme ulaşmayı kolaylaştıracaktır. Böylece örgütün otorite ve etkinlik sorunu bakımından da önemli bir kazanım elde edilecektir.

BM Güvenlik Konseyi'nin yukarıda ifade edilen şekilde yapısal bir değişime uğraması ya da lağvedilerek yetkilerinin Genel Kurul'a devredilmesi de otorite ve etkinlik sorununun çözülmesi açısından katkı sunacaktır. Ancak devletlerin güç odaklı politikaları, rekabet unsuru, daimi üyelerin politikaları ve perspektifleri ve sistemden reformist ya da revizyonist bir beklenti içerisinde olan devletlerin talepleri dikkate alındığında burada dile getirilen önerilerin gerçekleşmesinin pek mümkün olmadığını söylemek gerekir. Bu açıdan örgütün ancak sistemik çapta bir kriz olduğunda ve statükocu ve revizyonist güçler arasındaki mücadelenin küresel çapta gerçekleşmesi halinde bir değişim geçireceği ya da Milletler Cemiyeti'nin akıbetine uğrayarak varlığının son bulacağı dahi iddia edilebilir. Ancak örgütün yapısında köklü bir değişimin veya varlığının ortadan kalkmasının kısa vadede gerçekleşmeyeceği uzun vadede ise gündemde olabileceği söylenebilir.

Sonuç olarak; çalışmada tespit edildiği üzere güç dengesi geçmişte olduğu gibi günümüzde de devletler ve uluslararası sistem açısından geçerlilik taşıyan bir politika olarak hala güncelliğini korumaktadır. Bu kapsamda; rekabet, çatışma ve göreceli çıkarlar gibi unsurların dikkate alınması gerektiği söylenebilir. Bu nedenle devletler güç dengesini kendi lehlerine sağlamak için güçleri oranında çeşitli politikalar ve uygulamalar ile çaba göstermektedirler. Bu bağlamda BM gibi uluslararası örgütlerin de araçsallaştırıldığı görülmektedir. Söz konusu durum, gerek Güvenlik Konseyi'nde gerekse Genel Kurul'da yaşanan karar alma süreçleri ve örgüte dair reform talepleri göz önüne alındığında somut olarak görülmektedir. Bu yüzden Birleşmiş Milletler'in Güç Dengesi Teorisi açısından geçerlilik taşıdığı ve teori kapsamında analiz edilebileceği tespitini yapmak mümkündür. 


\section{Kaynakça}

Ataman, Muhittin (2003) "The Impact of Non-State Actors on World Politics: A Challenge to Nation-States", Alternatives: Turkish Journal of International Relations, C. 2, S. 1, ss. 42-66.

Baehr, Peter R., Gordenker, Leon (2005) The United Nations: Reality and Ideal, 4. Bask1, Palgrave Macmillan, New York.

Bailey, Sydney D., Daws, Sam (1995) The United Nations A Concise Political Guide, 3. Bask1, Macmillan Press, London.

Brooks, Stephen G., Wohlforth, William C. (2005) "Hard Times for Soft Balancing”, International Security, C. 30, S. 1, ss. 72-108.

Claude, Inis L., Jr. (1962) Power and international relations, Random House, New York.

Claude, Inis L., Jr. (1989) “The balance of power revisited”, Review of International Studies, C. 15, S. 2, ss. $77-$ 85 .

Chatterjee, Partha (1972) "The Classical Balance of Power Theory", Journal of Peace Research, C. 9, S. 1, ss. $51-61$.

Danilovic, Vesna (2005) When the Stakes Are High Deterrence and Conflict among Major Powers, The University of Michigan Press, Michigan.

Duchêne, Alexandre (2008) Ideologies across Nations: The Construction of Linguistic Minorities at the United Nations, Mouton de Gruyter, Berlin.

Gordon, Joy (2014) "The United Nations Security Council and the Emerging Crisis of Legitimacy”, Yale Journal of International Affairs, C. 9, S. 1, ss. 40-47.

Haas, Ernst B. (1953) “The Balance of Power: Prescription, Concept, or Propaganda”, World Politics, C. 5, S. 4, ss. $442-477$.

Kaplan, Morton A. (1957) "Balance of Power, Bipolarity and Other Models of International Systems", The American Political Science Review, C. 51, S. 3, ss. 684-695.

Keskin, Funda (2002) "New Challenges Facing the United Nations", Turkish Yearbook of International Relations, C. 33, ss. 271-284.

Latif, Dilek (2000) "United Nations' Changing Role in the Post-Cold War Era", The Turkish Yearbook of International Relations, C. 30, ss. 23-66.

Lim, Chin Leng (2007) "The Great Power Balance, the United Nations and What the Framers Intended: In Partial Response to Hans Köchler”, Chinese Journal of International Law, C. 6, S. 2, ss. 307-328.

Little, Richard (2007) The Balance of Power in International Relations: Metaphors, Myths and Models, Cambridge University Press, New York.

Lupu, Yonatan (2006) "Rules, Gaps and Power: Assessing Reform of the U.N. Charter", Berkeley Journal of International Law, C. 24, S. 3, ss. 881-907. 
Mearsheimer, John J. (2013) "Structural Realism”, Tim Dunne, Milja Kurki ve Steve Smith (Ed.); International Relations Theories Discipline and Diversity, 3. Bask1, Oxford University Press, Oxford, ss. 77-93.

Morgenthau, Hans J. (1948) Politics Among Nations The Struggle For Power, Alfred A. Knopf, New York.

Pape, Robert A. (2005) “Soft Balancing against the United States”, International Security, C. 30, S. 1, ss. 7-45.

Pijovic, Nikola (2012) "The Relative Gains Theorem and the Stalling United Nations Security Council Membership Reform”, Alternatives: Turkish Journal of International Relations, C. 11, S. 4, ss. 32-41.

Roskin, Michael G., Berry, Nicholas O. (2014) Uluslararası İlişkiler: Uİ’nin Yeni Dünyası (Çev. Özlem Şimşek), 1. Baskı, Adres Yayınları, Ankara.

Rudd, Kevin (2016) “UN 2030: Rebuilding Order in a Fragmenting World”, International Peace Institute, ss. 1 74. https://www.ipinst.org/wp-content/uploads/2016/08/IPI-ICM-UN-2030-Chairs-Report2FINAL.pdf, (Erişim Tarihi: 21.05.2019).

Russell, Ruth B. (1970) ““"Power Politics” and the United Nations”, International Journal, C. 25, S. 2, ss. 321332.

Schweller, Randall L. (2016) The Balance of Power in World Politics, https://oxfordre.com/politics/view/10.1093/acrefore/9780190228637.001.0001/acrefore-9780190228637-e119?print=pdf ss. 1-20, (Erişim Tarihi: 10.05 .2019$)$

Sengupta, Somini (2017) The United Nations Explained: Its Purpose, Power and Problems, The New York Times, https://www.nytimes.com/2017/09/17/world/americas/united-nations-un-explainer.html (Erişim Tarihi: 01.06.2019).

Sheehan, Michael (1996) The Balance of Power History and Theory, Routledge, New York.

Shraideh, Saleh Al (2017) "The Security Council's Veto in the Balance”, Journal of Law, Policy and Globalization, C. 58, ss. 135-145.

Thérien, Jean Philippe (2015) “The United Nations Ideology: From Ideas to Global Policies”, Journal of Political Ideologies, C. 20, S. 3, ss. 221-243.

Walt, Stephen (1985) “Alliance Formation and the Balance of World Power”, International Security, C. 9, S. 4, ss. $3-43$.

Wight, Martin (1966) “The Balance of Power", Herbert Butterfield, Martin Wight (Ed.); Diplomatic Investigations Essays in the Theory of International Relations, Cambridge, Harward University Press, Massachusetts, ss. 149-175.

Young, Oran R. (1968) “The United Nations and the International System”, International Organization, C. 22, S. 4, ss. $902-922$.

Zinnes, Dina A. (1967) “An Analytical Study of the Balance of Power Theories”, Journal of Peace Research, C. 4, S. 3, ss. 270-287. 